\title{
Sınıf Öğretmeni Adaylarının Öğretmenlik Mesleği Konusundaki Görüşleri ve Geleceğe Yönelik Beklentileri
}

\author{
Kismet DELIVEL $\dot{I}^{1}$
}

\section{- Geliş Tarihi: 27.08.2020 • Kabul Tarihi: 26.11.2020 • Çevrimiçi Yayın Tarihi: 27.11.2020}

\section{$\ddot{O} \mathbf{z}$}

$\mathrm{Bu}$ çalışmanın amac1, sınıf öğretmenliği son sınıfta okuyan öğretmen adaylarının öğretmenlik mesleği konusundaki düşüncelerini, öğretmenlik mesleğini tercih etme sebeplerini, öğretmenlik mesleğine yönelik beklentilerini ve olanaklar mümkün olsa hayatta olmasını istedikleri şeylerin neler olduğunu anlamaya çalışmaktır. Çalışma nitel araştırma yaklaşımlarından olgubilim yöntemine göre tasarlanmıştır. Araştırmanın çalışma grubu amaçlı ve benzeşik örnekleme yöntemi ile oluşturulmuştur. 2015-2016 yılında Muğla Sttkı Koçman Üniversitesi Eğitim Fakültesi, sınıf öğretmenliği son sınıfta okuyan 42 (21 k1z ve 21 erkek) öğretmen adayının görüşlerine başvurulmuştur. Veriler katılımcıların yaşam öyküleri, yarı yapılandırılmış görüşme formu (3 soru) ve arzu listesinde yer alan sorular (4 soru) ile toplanmış, içerik analizi ve betimsel analiz yöntemleriyle analiz edilmiş; bulgular "öğretmen adaylarının öğretmenlik mesleğine ilişkin görüşleri ve geleceğe yönelik beklentileri” olmak üzere iki temada değerlendirilmiştir. Araştırma sonucunda, öğretmen adaylarının çoğunluğunun öğretmenlik mesleğinin daha çok dezavantajlı yönlerine vurgu yaptıkları, sınavla öğretmen atamalarının yapılmasını, öğretmenlik statüsünün düşük olmasını, öğretmenlerin çalışma şartlarının adil olmamasını ve lisans düzeyinde verilen eğitimin teorik olmasını eleştirdikleri anlaşılmıştır. Bu bulgulara dayanarak, öğretmenlik mesleğinin statüsünü yükseltecek önlemler alınması, öğretmenlerin çalışma koşullarının iyileştirilmesi, seçme/yerleştirme ve atama sınavlarının gözden geçirilmesi, lisans düzeyinde verilecek eğitimin teorik ve uygulamalı olacak şekilde yapılması önerilmiştir.

Anahtar sözcükler: Sınıf öğretmenliği, öğretmen adayı, öğretmenlik mesleği, beklentiler

\section{Atıf:}

Deliveli, K. (2021). Sınıf öğretmeni adaylarının öğretmenlik mesleği konusundaki görüşleri ve geleceğe yönelik beklentileri. Pamukkale Üniversitesi Eğitim Fakültesi Dergisi, 51, 393427.doi:10.9779.pauefd. 774418

\footnotetext{
1 Kısmet Deliveli, Öğr. Gör. Dr. Muğla Sitkı Koçman Üniversitesi, Eğitim Fakültesi, ORCID: 0000-0003-3035-7505, dikismet@mu.edu.tr,
} 


\section{Giriş}

Türkiye'de her kademedeki öğretmen ihtiyacının karşılanması için, öğretmenlik mesleğinde karar kılan gençlerin öncelikli olarak eğitim fakülteleri olmak üzere üniversiteler aracılığıyla lisans eğitimi almaları gerekmektedir. Milli Eğitim Bakanlığı (MEB) da kamuda görev almak isteyen öğretmen adaylarının işvereni konumundadır. 1980’li yıllardan başlayarak Türkiye'de yeni bir yönetsel anlayışının benimsenmesinin sonucu olarak özel sektörde olduğu gibi kamuda da öğretmen istihdamında esnek istihdam modeli uygulamaktadır. Bakanlık sayıları her geçen gün artan eğitim fakültesi mezunlarının açıkta kalmalarına neden olan, stres yaratan ve arz-talep dengesini bozan "kadrolu, sözleşmeli, ücretli öğretmenlik" gibi farklı uygulamalarla öğretmen istihdamı sağlamaya çalışmaktadır (Soydan, 2012; Çınkır ve Kurum, 2017).

Bakanlıkça istihdam edilecek öğretmen adaylarının, öncelikle 4 yıllık eğitimi başarıyla bitirmeleri ve Kamu Personeli Seçme Sınavı'nda (KPSS) gerekli puanı almaları gerekmektedir. Adaylık döneminde ise atandıkları illerde Milli Eğitim Bakanlığı'nca hazırlanmış olan mesleki uyum programlarına katılmaktadır (MEB, 2013). Milli Eğitim Bakanlığı'nın resmi eğitim kurumlarına aday öğretmen olarak atananların yetiştirme sürecine ilişkin usul ve esasları düzenleyen yönergeye göre, aday öğretmenler göreve başladıkları okullarda adaylıklarının ilk altı ayında yetiştirme sürecine tabi tutulmaktadır. Yetiştirme süreci, okul müdürü ve danışman öğretmenin sorumluluğunda "sınıf ve okul içi, okul dışı faaliyetler ile hizmet-içi eğitim seminerlerinden” oluşmaktadır (MEB, 2016a). Yetiştirme sürecinde okul yöneticileri ve danışman öğretmenleri rehberliğinde adaylar uygulamalar gerçekleştirmektedir ve bu süreçte il ve ilçe milli eğitim müdürlerinin çeşitli görev ve sorumlulukları bulunmaktadır (MEB, 2016b). Aday öğretmenlerin bakanlık tarafından yapılan yazılı ve sözlü sınava girebilmesi için de en az bir yıl fiilen çalışması ve performans değerlendirme sınavlarında başarılı olmaları beklenmektedir (MEB, 2015). Adayların ilk performans değerlendirme sınavı adayın eğitiminden sorumlu okul idaresi ve rehber öğretmen tarafından yapılırken, iki ve üçüncü performans değerlendirme sınavları adayın atandığı okulda yapılmaktadır (MEB, 2016a).

Adaylık sürecinde MEB'ce uygulanan aday yetiştirme programının amacı, mesleğin ilk yıllarında öğretmen adaylarının karşılaşabilecekleri güçlükleri en aza indirgemek ve mesleğe hazır oluşla ilgili bilgi ve becerilerini artırmaktır. Bu program aracılığıyla adayın gerek okul ve sınıf düzeyinde gerekse okul dışında mesleğe uyumunu sağlayacak bilgi ve 
beceriler kazandırılmaya çalışılmaktadır (MEB, 2016b). Adaylık süreci eğitim programlarının öğretmenlik mesleği konusunda adayların mesleğe uyum sürecine olumlu etkileri vardır ve bu süreçte adaylar mesleki anlamda yeni deneyimler kazanabilmektedir (Ingersoll ve Strong, 2011; Tunçbilek ve Tünay, 2017).

Öğretmen adaylarının kendilerini mesleğe hazır hissetmeleri için, gerek hizmet öncesi ve gerekse adaylık sürecinde iyi yetiştirilmeleri gerekir (Beare, Marshall, Torgerson, Tracz ve Chiero, 2012; Brown, Lee ve Collins, 2015). Dolayısıyla, öğretmen yetiştiren kurumlarda lisans eğitimleri sırasında öğretmen adaylarına öğretmenlik mesleğine yönelik bilgi ve beceriler kazandırılırken, bilgiyi öğrenciye nasıl aktarabileceğinin öğretilmesi gereklidir. Göreve atandıktan sonra mesleğe uyumlarını sağlayacak desteklerin ise sadece adaylık süreci eğitimiyle sınırlı kalmaması, aksine uzun süreli olacak şekilde genç öğretmenlere sürekli rehberlik sağlanması önemlidir. Bu süreçte adaylara atandıkları bölgenin ve yerleşim yerinin şartlarına (okul, okul çevresi, öğrenciler, aileler vs.) nasıl uyum sağlayacakları konusunda bilgilendirmeler yapılırken, karşılaştıkları sorunların çözümünde MEB'ce destek olunmalıdır. Çünkü her bir adayın atanacağı okul bölgesinin fiziki ve sosyal yapısı (ailelerin sosyo-ekonomik durumları, bölgenin kültürel yapısı, sosyal ilişkiler vs.) okul ortamı ve çevresinin imkânları (aileler, öğrenciler, okulun maddi kaynakları, okula sunulan kaynaklar vs.) farklı olabilmektedir.

Türkiye'de mesleğe yeni atanan öğretmenler yetiştirme süreci sonunda genellikle öğretmen ihtiyacının yoğun olduğu kırsal bölgelere gönderilmektedirler. Öğrencilikten henüz çıkan aday öğretmenler hiç bilmedikleri bölgelere atandıklarında, yeni kültürel ortama ve mesleğe uyum sağlamaya çalışırken bölgenin ya da yerleşim yerine bağlı olarak farklı sorunlarla karşılaşabilmektedir (Toker-Gökçe, 2013). Aday öğretmenler çoğunlukla kırsal bölgelerdeki (mezra, köy, kasaba, mahalle) okullara atandıklarında hiç alışık olmadıkları yeni bir çevreye alışırken bazı sorunlarla karşılaştıklarında, yaşam şartlarına uyum genç öğretmen açısından mesleğin cazibesinin azalmasına neden olabilmektedir. Nitekim, bu konuyu tartışan araştırmacılar (Aksoy, 2008; Başar ve Doğan, 2015; Duran, Sezgin ve Çoban, 2011; Gömleksiz, Kan, Biçer ve Yetkiner, 2010; Korkmaz, Saban ve Akbaşl1, 2004; Sarı ve Altun, 2015; Taşkaya, Turhan ve Yetkin, 2015; Yeşilyurt ve Karakuş, 2011) araştırmalarında öğretmen adaylarının hem deneyimsiz hem de farklı sosyal çevrelerden gelmiş olmalarından dolayı, mesleğin ilk yıllarında karşılaştıkları sorunların üstesinden gelemediklerini, mesleğe, okul ve ortama alışmada uyum sorunu yaşadıklarına dikkat çekmişlerdir. 
$\mathrm{Bu}$ araştırmacilardan, Yeşilyurt ve Karakuş (2011), köy ve kent merkezine atanan farklı branş öğretmen adaylarıyla yaptıkları araştırmalarında lisans eğitimlerini şehir merkezlerinde alıp, fiziksel ve sosyal şartlar açısından köy, mezra, birleştirilmiş sınıf vb. yerlerde göreve başlayan adayların bulunduğu ortama uyum sağlamada ve mesleki bilgiyi aktarmada sorunlarının olduğunu tespit etmişlerdir. Özellikle tecrübesiz olmaları nedeniyle en fazla öğrencilerle iletişim kurma, sınıfı etkili yönetme problemleri yaşadıklarını, görev yaptıkları okulda fiziksel yaşam koşullarının zorluğundan şikâyetçi olduklarını belirlemişlerdir.

Öğretmenlik mesleğine uyum süreci bölgenin sosyo-ekonomik yapısına, okul ve okul çevresinin olanaklarına bağlı olarak kimi zaman sınıf öğretmenleri açısından daha zorlayıcı olabilmektedir. Kırsal bölgenin (köy, mezra gibi) yaşam koşulları, eğitim-öğretim sürecinde karşılaşılan güçlükler sınıf öğretmenlerinin ilk kez atandıkları okula ve okul çevresine uyumunu güçleştirebilmektedir. Bu konuda Korkmaz vd., (2004) göreve yeni başlayan sınıf öğretmenlerinin büyük bir çoğunluğunun gerek öğretmenlik mesleğine uyum sağlama ve gerekse mesleği başarılı bir şekilde icra etmede yaşadıkları zorluklara işaret etmiştir. Aksoy (2008), branş öğretmenlerinden farklı olarak, birleştirilmiş sınıfların olduğu okullara atanan sınıf öğretmenlerinin gerek okul çevresi, gerekse okul düzeyinde farklı sorunların üstesinden gelmek zorunda kaldıklarını belirtmiştir. Taşkaya vd., (2015) kırsal kesimde görev yapan sınıf öğretmenlerin karşı karşıya oldukları sorunların çok daha fazla olduğunu belirtmiş, öğretmenlerin çevre (ulaşım, güvenlik, su, temizlik, sağlık hizmetinin yetersizliği) ve eğitimöğretim (öğrenci ve velilerin eğitime ilgisizliği, oryantasyon problemi, öğretmenlerin deneyim eksikliği, öğrenci devamsızlığı, öğretmenlerin isteksizliği), özlük hakları (öğretmen sirkülasyonu-tayini, ısınma, barınma) okulların fiziki durumu ve imkanları (1sınma, donanım ve eğitim materyali eksikliği, derslik eksiği-yetersizliği, WC olmayış1-yetersizliği vb.) gibi konularda sorunlar olduğunu dile getirdiklerini belirlemişlerdir. Duran vd. (2011), aday sınıf öğretmenlerinin uyum ve sosyalleşme sürecini inceledikleri araştırmalarında, çevreye uyum noktasında aday öğretmenlerin daha çok barınma ve alıştığ şehir hayatından uzak olma; sonra sırasıyla, teknoloji/teknolojik gelişmeler ile sosyal faaliyetlerden, aile, arkadaş ve dostlarından uzak olma; yöre halkı ile iletişim kuramama ve beslenme gibi sorunlar yaşadıklarını; kurum kültürüne uyum ve örgütsel sosyalleşme noktasında da daha çok temel ve hazırlayıcı eğitim süreci, ailelerle iletişim, kurumsal uzmanlık alanlarını algılamada sorun yaşadıklarını tespit etmişlerdir. Sarı ve Altun (2015) göreve yeni başlayan sınıf öğretmenlerinin öğrencilerin motivasyonlarını nasıl arttıracaklarını bilmediklerini ortaya 
koymuşlardır. Bu sonuçlar, mesleğe yeni başlayan branş ya da sınıf öğretmenlerinin ne tür sorunlarla karşılaştıklarının anlaşılması bakımından önemlidir. Bu konuda Başar ve Doğan (2015) ve Gömleksiz vd., (2010) mesleğin ilk yılında sorun yaşayan ve bu sorunları nasıl çözeceklerini bilemeyen ve aday öğretmenlerin motivasyonlarını kaybedip, mesleğe olan inançlarının azalabileceğine dikkat çekmiştir. Öğretmenlerin mesleğin ilk yıllarında karşı karşıya kaldıkları sorunların onların meslekte kalıp kalmamasına neden olabileceği (Karge, 1993; Quaglia, 1989) düşünülürse mevcut sorunlarla baş edemeyen öğretmenlerin öğretmenlik mesleğini gönüllü olarak yerine getiremeyeceği söylenebilir. Bu durum öğretmenlik mesleğini seçme konusunda gençlerin endişe duymalarına sebep olabilir.

Gençlerin öğretmenlik mesleğini seçebilmesi için öğretmenlik mesleğini daha cazip hale getirecek uygulamalar ile düzenlemelere yer verilmesi sorunların çözümüne katk1 getirebilir. Buna karar verirken ise mesleğe yeni atanan/atanacak öğretmen adaylarının öğretmenlik mesleğini nasıl algıladıklarının ve mesleğe ve geleceğe yönelik beklentilerinin dikkate alınması yararlı olabilir. Yapılacak iyileştirmeler öğretmenlik mesleğini seçen/seçecek olan gençlerin mesleki yaşamlarında verimliliklerini, motivasyonlarını, tutumlarını olumlu yönde etkileyebilir. Bu düşünceden hareketle bu çalışmada öğretmenlik mesleğinin güçlü bir kariyer arzusu uyandıracak bir meslek haline dönüştürülmesi ve öğretmenlik mesleğinin standartlarının geliştirilmesi için öğretmenlik mesleğini seçen sınıf öğretmenliği son sınıfta okuyan gençlerin öğretmenlik mesleğine yönelik düşünceleri ve meslek seçimine yönelik beklentileri incelenmek istenmiştir.

\section{Araştırmanın amacı}

$\mathrm{Bu}$ çalışmanın amacı, sınıf öğretmenliği son sınıfta okuyan öğretmen adaylarının öğretmenlik mesleği konusundaki düşüncelerini, öğretmenlik mesleğini tercih etme sebeplerini, öğretmenlik mesleğine yönelik beklentilerini ve olanaklar mümkün olsa hayatta olmasını istedikleri şeylerin neler olduğunu anlamaya çalışmaktır. Araştırma amacına bağlı olarak aşağıdaki 4 alt probleme yanıt aranmıştır. Öğretmen adaylarının;

1. Türkiye'de öğretmenlik mesleği konusundaki düşünceleri nasıldır?

2. Öğretmenlik mesleğini seçme nedenleri nelerdir?

3. Gençlerin öğretmenlik mesleğini seçmesi/tercih edebilmesi için yapılması gerekenler konusunda önerileri nelerdir?

4. Beklentilerini karşılayacak her türlü olanağı elde etselerdi yaşamlarında neleri değiştirmek istedikleriyle ilgili görüşleri nasıldır? 


\section{Yöntem}

$\mathrm{Bu}$ araştırmada bireylerin tecrübe ettikleri konuya ilişskin fenomenleri nasıl algıladıkları, ne anladıkları ve nasıl deneyimledikleri belirlenmesi hedeflendiğinden çalışma nitel araştırma yaklaşımlarından olgubilim yöntemine göre tasarlanmıştır (Merriam, 2014; Punch, 2014).

\section{Çalışma Grubu}

Çalışma grubunun seçiminde olasılıklı olmayan, amaçlı örnekleme yöntemlerinden benzeşik örnekleme yöntemi kullanılmıştır. Benzeşik örnekleme yönteminin seçiminde amaç incelenecek konuya odaklanmak, çeşitliliği azaltmak, analizi basitleştirebilmek olduğundan, küçük ve homojen bir grup örneklem olarak ele alınmaktadır (Yıldırım ve Şimşek, 2018). Araştırmanın çalışma grubunu 2015-2016 yılında Muğla Sıtkı Koçman Üniversitesi Eğitim Fakültesi, Sınıf Öğretmenliği Ana Bilim Dalı 4. Sınıf öğrencilerinden mezuniyet aşamasında olan 21 Erkek (E) ve $21 \mathrm{~K} ı$ (K) olmak üzere toplam 42 öğretmen adayı oluşturmaktadır. Aşağıda çalışmaya katılan öğretmen adaylarıyla ilgili genel bilgiler paylaşılmıştır (Tablo 1).

Tablo 1. Öğretmen Adaylarlyla İle İlgili Genel Bilgiler

\begin{tabular}{lll}
\hline Sıra No-Cinsiyet & Yaş & Kazanmak İsteği Okul/Meslek \\
\hline Ö1-E & 23 & Psikolojik Danışmanlık ve Rehberlik \\
Ö2-K & 22 & Güzel Sanatlar-Resim \\
Ö3-K & 22 & Sinıf Öğretmenliği \\
Ö4-K & 22 & Tiyatro/Oyunculuk \\
Ö5-K & 22 & Psikolojik Danışmanlık ve Rehberlik \\
Ö6-K & 22 & Sinıf Öğretmenliği \\
Ö7-K & 23 & Sinıf Öğretmenliği \\
Ö8-K & 22 & Sosyal Hizmetler \\
Ö9-K & 21 & Sinıf Öğretmenliği \\
Ö10-K & 21 & Hemşirelik \\
Ö11-E & 21 & Sinıf Öğretmenliği \\
Ö12-K & 22 & Sinıf Öğretmenliği \\
Ö13-E & 23 & Sinıf Öğretmenliği \\
Ö14-E & 22 & Sinıf Öğretmenliği \\
Ö15-K & 21 & Sinıf Öğretmenliği \\
Ö16-K & 21 & Sinıf Öğretmenliği \\
Ö17-K & 23 & Sinıf Öğretmenliği \\
\hline & &
\end{tabular}




\begin{tabular}{|c|c|c|}
\hline Ö18-E & 21 & Sınıf Öğretmenliği \\
\hline Ö19-K & 21 & Sinıf Öğretmenliği \\
\hline Ö20-E & 22 & Sınıf Öğretmenliği \\
\hline Ö21-K & 20 & Mimarlık \\
\hline Ö22-E & 23 & Psikolojik Danışmanlık ve Rehberlik \\
\hline Ö23-K & 21 & Tiyatro/Oyunculuk \\
\hline Ö24-K & 24 & Sınıf Öğretmenliği \\
\hline Ö25-E & 22 & Milli Savunma (Askerlik) \\
\hline Ö26-K & 23 & Psikolojik Danışmanlık ve Rehberlik \\
\hline Ö27-K & 21 & Sınıf Öğretmenliği \\
\hline Ö28-E & 22 & Sınıf Öğretmenliği \\
\hline Ö29-E & 22 & Sınıf Öğretmenliğ \\
\hline Ö30-K & 23 & Psikolojik Danışmanlık ve Rehberlik \\
\hline Ö31-E & 22 & Sınıf Öğretmenliği \\
\hline Ö32-E & 22 & Avukatlik \\
\hline Ö33-E & 23 & Sınıf Öğretmenliği \\
\hline Ö34-E & 22 & Sınıf Öğretmenliği \\
\hline Ö35-E & 23 & Sınıf Öğretmenliği \\
\hline Ö36-E & 22 & Sınıf Öğretmenliğ \\
\hline Ö37-E & 23 & Sınıf Öğretmenliği \\
\hline Ö38-E & 22 & Psikolojik Danışmanlık ve Rehberlik \\
\hline Ö39-E & 22 & Sınıf Öğretmenliği \\
\hline Ö40-E & 22 & Sınıf Öğretmenliği \\
\hline Ö41-E & 22 & Sınıf Öğretmenliği \\
\hline Ö42-E & 23 & Sınıf Öğretmenliği \\
\hline
\end{tabular}

Tablo 1'de görülebileceği gibi ismi gizli tutulan her bir katılımcıya 1'den 42' ye kadar sıra numarası verilmiş, sayıların yanlarına katılımcının cinsiyetlerini gösteren harfler (erkekler için: E, kızlar için: K harfi) ile son kısma katılımcının yaşını gösteren rakamlar eklenmiştir. Buna göre araştırmaya 6. sırada katılan 22 yaşındaki kız öğretmen adayının kazanmak istediği okul Eğitim Fakültesi Sınıf Öğretmenliği Programı’dır.

\section{Veri Toplama Araçları}

Veriler araştırmacı tarafından hazırlanan yarı yapılandırılmış görüşme formu ile elde edilmiştir. Katılımcılarla görüşmelere başlamadan önce alan yazın taraması yapılarak 
araştırmacının hazırladığı görüşme formlarındaki sorular, alanda uzman iki akademisyen tarafından incelenmiş ve soruların anlaşılırlı̆̆ 1 test edilmiştir. Görüşmelere geçilmeden önce, araştırmaya gönüllü olarak destek veren çalışma grubunu oluşturan öğretmen adaylarına araştırmanın amacı açıklanmıştır.

2015-2016 öğretim yılında dönem başı ve dönem sonu olmak üzere çalışma grubunu oluşturan öğretmen adaylarıyla iki kez görüşme gerçekleştirilmiştir. Her bir görüşme öncesi, öğretmen adaylarına kendilerine sunulan görüşme formunda yer alan soruları samimi bir şekilde cevaplamalarının önemli olduğuna dikkat çekilmiştir. İlk tur görüşmelerde öğretmen adaylarının öğretmenlik mesleği konusundaki düşüncelerini, mesleği seçme nedenlerini ortaya koyabilmek için öğretmen adaylarının 3 açık uçlu soruya yazılı olarak cevap vermeleri istenmiştir. Bu sorular:

1. Kariyer tercihi bakımından değerlendirdiğinizde Türkiye'de öğretmenlik mesleği konusundaki düşünceleriniz nelerdir? (avantaj-dezavantaj)

2. Öğretmenlik mesleğini seçme nedenleriniz hakkında biraz bilgi verebilir misiniz?

3. Gençlerin öğretmenlik mesleğini seçme ya da tercih etme noktasında yüreklendirilmesi için neler yapılmasını istersiniz?

İkinci tur görüşmelerde ise öğretmen adaylarının otobiyografilerini anlatmaları ve Arzu Listesi'nde yer olan soruları cevaplamaları istenmiştir. Otobiyografiler (yaşam öyküleri) kişilerin kendi yaşamlarını nasıl deneyimledikleri ve nasıl gördüklerini anlama açısından katkı sunabilir (Kakuru ve Paradza, 2007). Yaşam öyküleri kişisel duygu ve deneyimlerin daha da netleşmesi ve bireyin yaşantısına daha fazla anlam katması anlamında yararlı olabileceği gibi, başkalarının da bireyi daha önce hiç fark edemedikleri yönlerinin anlaşılmasına hizmet edebilir (Atkinson, 2004). Ayrıca yaşam öyküleri kişilerin kendileri hakkında daha derin düşünerek geleceğe yönelik karşılaşabilecekleri olumsuzlukları aşmalarına yardım edebilir (Yang, 2008). Eğitim araştırmalarında yaşam öyküleri öğretmenlerin bireysel olarak yaşamlarını, mesleki anlamda da kariyerlerini nasıl değerlendirdikleri ve mesleki uygulamalarına yönelik tutum, davranış ve duygularının anlaşılması amaçlı kullanılmıştır (Goodson, 1997). Kendini anlatmaya dayalı test dışı tekniklerinden biri olan ve düzenlenen yarım kalmış ifadelerden (tamamlanmamış cümlelerden) ve sorulardan oluşan Arzu (istek) Listeleri de çocuk veya gencin doyurulmamış ihtiyaçlarını, açığa vuramadığı duygularını, umut ve beklentilerini ortaya çıkarmak amacıyla tercih edilen bir yöntemdir (Karataş ve Yavuzer, 2015). Bu çalışmada öğretmen adaylarının yaşamlarını nasıl değerlendirdikleri gelecekten ne tür beklentiler 
içinde olduklarının anlaşılması amacıyla yaşam öyküleri incelenmek istenmiştir. Ayrıca öğretmen adaylarının yaşam öykülerinde anlatamadıkları veya ifade edemedikleri durumları (beklentiler, hedefler) ortaya çıkartabilmek amacıyla araştırmacı öğretmen adaylarının Arzu Listesi'nde yer alan 4 açık uçlu soruya verdikleri cevapları iki tür veriyi karşılaştırmak için değerlendirmek istemiştir. Arzu Listesi'nde yer alan bu sorular:

1. İstediğiniz kadar paranız olsaydı ne yapardınız?

2. Her türlü olanağınız bulunsa hangi mesleği seçmek isterdiniz?

3. Masallardaki gibi bir peri 'dile benden ne dilersen' deseydi, en önemli üç dileğiniz ne olurdu?

4. Öğretmenlik mesleğinde mutlu olabilmeniz için nelerin değişmesini isterdiniz?

\section{Veri Analizi}

Nitel araştırma yaklaşımına göre tasarlanan ve sınıf öğretmenliği eğitimi programına kayıtlı son sınıf öğrencilerinin görüşlerinin incelendiği bu araştırmada elde edilen verilerin analizinde 'içerik ve betimsel analiz yöntemleri' kullanılmıştır (Yıldırım ve Şimşek, 2018). Nitel araştırmalarda katılımcıların demografik özelliklerinin ve farklı yönlerinin tasvir edilmesi, bir kişinin yaşam öyküsünün özetlenmesi gibi durumlarda betimsel analiz yöntemi kullanılabilmektedir (Miles ve Huberman, 1994). İçerik analizinde de toplanan veriler daha ayrıntılı incelenerek ve bu verileri açıklayan kavram, kategori ve temalara ulaşılır. Elde edilen veriler değerlendirilirken sıklıkla tekrarlanan ya da katılımcıların yoğun vurguladıkları olgu ve olaylardan kodlar çıkarılırken, ilişkili olan verilerden (kodlardan) belirli kavramlara (kategorilere), kavramlardan temalara ulaşılır. Bu yolla katılımcı görüşlerinin muhtevası sistematik bir şekilde okuyucuya sunulmaya çalışılır (Merriam ve Grenier, 2019). Bu çalışmada da içerik analiz yöntemiyle öğretmen adaylarının aktardığ1 görüşlerin içeriği kodlar, temel kavramlar ve temalar altında birleştirilmiştir. Betimsel analiz yöntemi ile öğretmen adaylarının bakış açıları yansıtılırken her bir temada "Ö1, Ö2, Ö3.." şeklinde katılımcı kodu kullanılmış ve alıntılar yapılırken yaşam öykülerinden kesitler sunulmuştur.

Veriler analiz edilirken ilk olarak öğretmen adaylarının birinci ve ikinci tur görüşmeler sırasında verdikleri cevaplar; daha sonra ise 42 katılımcının görüşme formlarına aktardığı ifadeler okunurluk açısından incelenmiştir. Her bir görüşme sırasında öğretmen adaylarının görüşlerini yansıttıkları ifadeler dikkatli bir şekilde okunarak sorular bazında incelendikten sonra ortaya çıkan temalar altında kodlamalar yapılmıştır. Tablolar halinde 
düzenlenen tema ve kodların frekans ve yüzdeleri de hesaplanarak öğretmen adaylarının görüşleri sistemli bir şekilde sunulmaya çalışılmıştır.

\section{Geçerlik ve güvenirlik}

$\mathrm{Bu}$ araştırmanın geçerlik ve güvenirlik ölçütlerini sağlamak amacıyla, nitel araştırmalarda geçerlik ve güvenirliğin sağlanmasında kullanılan "inandırıcılık (iç geçerlik), aktarılabilirlik (dış geçerlik), tutarlık (iç güvenirlik) ve teyit edilebilirlik (dış güvenirlik)” olmak üzere dört ölçüte bakılmıştır (Lincoln ve Guba, 1985).

\section{Inandırıcılık (iç geçerlik)}

Nitel araştırmalarda araştırma sonuçlarına ulaşırken izlenen sürecin, çalışılan gerçekliğin ortaya çıkarılmasında iç geçerlilik bakımından araştırmanın yeterliliğine bakılır. Araştırmacı bu süreçte anladığı düşündüğü olgu ve olayları gerçekçi bir biçimde sunup/sunamadığ üzerinde durmalıdır (Silverman, 2016). Bu ölçütü gerçekleştirebilmek için belirli stratejiler vardır. Araştırmanın gerçekleştirildiği durumun, katılımcıların ve temaların ayrıntılı bir şekilde betimlenmesi inandırıcılığı sağlamak için izlenen yollardan biridir. Çünkü ayrıntılı betimlemeler sunulması okuyucunun açıklamaları anlamlandırabilme fırsatı verdiği gibi, bulguların benzer durumlara uygulanabilirliği konusunda karar verme kolaylığı da sağlamaktadır (Creswell, 2014). Bir başka yol ise araştırma raporlaştırılırken, katılımcıların özellikleriyle ilgili bilgilerin verilmesidir (Johnson ve Christensen, 2008). Bu araştırmada da inandırıcılığı artırabilmek için, katılımcıların özellikleri konusunda bilgilere yer verilmiş, temalar halinde katılımcı görüşleri sunulurken betimsel bir dil kullanılmıştır.

\section{Aktarllabilirlik (dış geçerlik)}

Araştırma sonuçlarının benzer durumları tekrar edilebilirliği güvenirlik kavramı ile ilişkilidir. Nitel araştırmalarda, araştırma verilerinin elde edildiği ortama benzer bir ortamın tekrar elde edilmesi mümkün olmadığından araştırmanın aktarılabilir olma ölçütünün aranması gerekir (Patton, 2014). Bu ölçütün karşılanabilmesi için nitel araştırmalarda veriler detaylı bir şekilde betimlenir ve doğrudan alıntılara yer verilir (Yıldırım ve Şimşek, 2018). $\mathrm{Bu}$ çalışmada da aktarılabilirlik ölçütünü karşılamak için veriler detaylı bir şekilde sunulurken öğretmen adaylarının konuyla ilgili görüşlerinden alıntılar yapılmıştır Her bir temada öğretmen adaylarının görüşleri betimsel anlatımla sunulurken, alıntıların sonuna adayın sıra numarasını belirten 'Ö1' şeklinde kodlar kullanmıştır.

\section{Tutarlılık (içgüvenirlik)}

Nitel araştırmalarda tutarlık ölçütünü karşılamak için elde edilen bulguların tamamının yorum ve genelleme yapılmaksızın okuyucuya sunulması gerekmektedir (Meriam, 2014). 
$\mathrm{Bu}$ süreçte elde edilen veriler yorumlanırken doğru ve tutarlılık yönünden birbiriyle ilişkisi kurularak yorumlanmalıdır (Denzin ve Giardina, 2011). Bu çalışmada da tutarlılık ölçütünü karşılamak için öğretmen adaylarının kariyer tercihleri, kariyer tercih sebepleri ve öğretmenlik mesleğine yönelik beklentileriyle ile ilgili dönem başı ve dönem sonunda verdikleri cevaplar sürekli olarak karşılaştırılarak doğru ve tutarlı olacak şekilde aktarılırken, yorum ve genelleme yapılmadan okuyucuyla paylaşılmıştır.

\section{Teyit edilebilirlik (dış güvenirlik)}

Nitel araştırmalarda dış güvenirlik ölçütünü sağlamak üzere katılımcı görüşlerinin doğru yansıtılabilmesi için, sonuçların objektif bir şekilde yansıtılması gerekmektedir (Creswell, 2014). Bu ölçütün sağlanabilmesi için araştırmanın katılımcılar ile araştırma kapsamında değerlendirilen veri kaynaklarının açık bir şekilde belirtilmiş olması ve araştırma sonuçlarının da şeffaf bir şekilde rapor edilmesi gerekmektedir (Connelly, 2016). Bu ölçütün sağlanması için araştırmacı kendi konumunu açık hale getirirken, verileri elde ettiği bireyler ile sosyal ortamı, süreci tanıtmalı, verilerin analizinde kullandığı kavramsal çerçevenin varsayımlarını tanımlamalıdır (Yıldırım ve Şimşek, 2018). Bu çalışmada araştırmacı öğretmen adaylarının görüşlerini şeffaf bir şekilde, yansıtmaya özen göstermiş, sonuçları aktarırken objektif bir tutum sergilemiştir.

\section{Araştırmacının rolü}

Nitel araştırmalarda araştırmacılar araştırma süresince rolünü iyi tanımlamalı, katılımcı görüşlerini doğru yansıtabilmek için, araştırma süresince katılımcıların görüş ve düşüncelerini doğru bir şekilde anlamaya ve aktarmaya çalışmalıdır (Punch, 2014). Bu çalışmada araştırmacı, dönem başı ve dönem sonunda yaptığ görüşmeler sırasında empatik bir bakış açısı geliştirmeye çalışmış; katılımcıların düşüncelerini ve beklentilerini doğru yansıtabilmek için ise gerek verilerin elde edildiği süreçte ve gerekse verilerin analiz sürecinde kişisel görüş ve önyargılardan uzak bir tutum sergilemeye çalışmıştır.

\section{Bulgular}

$\mathrm{Bu}$ araştırmanın bulguları "öğretmen adaylarının öğretmenlik mesleğine ilişkin görüşleri ve geleceğe yönelik beklentileri” olmak üzere iki temada değerlendirilmiştir (Şekil 1). Her bir temada, alt kategoriler altında değerlendirmeler yapılırken öğretmen adaylarının görüşlerinden alıntılar aktarılmıştır. 


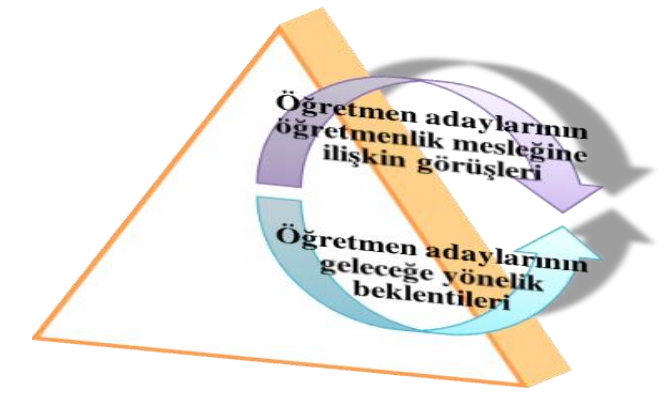

Şekil 1. Öğretmen adaylarının görüşlerinin değerlendirilmesi

\section{Öğretmenlik mesleğine ilişkin görüşler}

$\mathrm{Bu}$ temada öğretmen adaylarının öğretmenlik mesleğine ilişkin görüşleri incelenmiş ve adayların öğretmenlik mesleğine ilişkin görüşleri “öğretmenlik mesleğinin sunduğu olanaklar, öğretmenlik mesleğini seçme nedenleri” olmak üzere iki alt başlıkta incelenmiştir.

\section{Öğretmenlik mesleğinin sunduğu olanaklar (a)}

Öğretmenlik mesleğinin sunduğu olanaklar “mesleğin avantaj ve dezavantajları” olmak üzere iki alt boyutta değerlendirilmiştir (Tablo 2).

Tablo 2. Öğretmenlik mesleği konusundaki düşünceleri

\begin{tabular}{|c|c|c|c|c|}
\hline Öğretmenlik mesleği & Kadın & Frekans (f) & Erkek & Frekans (f) \\
\hline Avantajlar & & 21 & & 19 \\
\hline $\begin{array}{l}\text { Değişik yerleri görme } \\
\text { imkânı sağlaması }\end{array}$ & - & & Ö1 & $\mathbf{1}$ \\
\hline $\begin{array}{l}\text { Mesleki doyumunun } \\
\text { yüksek olduğunu } \\
\text { düşünmesi }\end{array}$ & $\begin{array}{l}\text { Ö2, Ö6, Ö7, Ö8, } \\
\text { Ö12, Ö16, Ö19, } \\
\text { Ö21, Ö23 }\end{array}$ & 9 & $\begin{array}{l}\text { Ö13, Ö18, } \\
\text { Ö28,Ö29,Ö33, } \\
\text { Ö36,Ö37, } \\
\text { Ö38,Ö41,Ö42 }\end{array}$ & 10 \\
\hline $\begin{array}{l}\text { Çalışma saatlerinin } \\
\text { uygun olması }\end{array}$ & $\begin{array}{l}\text { Ö3, Ö4, Ö5, } \\
\text { Ö7,Ö9, Ö15, } \\
\text { Ö16, Ö19, Ö21, } \\
\text { Ö23, Ö26, Ö27 }\end{array}$ & 12 & $\begin{array}{l}\text { Ö11, Ö14, Ö20, } \\
\text { Ö28,Ö31, } \\
\text { Ö34,Ö35,Ö40 }\end{array}$ & 8 \\
\hline Dezavantajlar & & 45 & & 35 \\
\hline Atamalar az & $\begin{array}{l}\text { Ö5, Ö8, Ö15, } \\
\text { Ö16, Ö24, } \\
\text { Ö26,Ö30 }\end{array}$ & 7 & $\begin{array}{l}\text { Ö1, } \\
\text { Ö11,Ö31,Ö33,Ö41 }\end{array}$ & 5 \\
\hline
\end{tabular}


olmas1

\begin{tabular}{|c|c|c|c|}
\hline $\begin{array}{l}\text { Öğretmenlik } \\
\text { mesleğinin statüsünün } \\
\text { düşük olması }\end{array}$ & $\begin{array}{l}\text { Ö2, Ö7, Ö10, } \\
\text { Ö12, Ö17, Ö19, } \\
\text { Ö25, Ö27,Ö32 }\end{array}$ & 9 & $\begin{array}{l}\text { Ö11, Ö13, Ö14, } \\
\text { Ö28,Ö29, } \\
\text { Ö31,Ö33,Ö35,Ö39 }\end{array}$ \\
\hline $\begin{array}{l}\text { Sinavla öğretmen } \\
\text { ataması yapılıyor } \\
\text { olması }\end{array}$ & $\begin{array}{l}\text { Ö3, Ö4, Ö9, } \\
\text { Ö15, Ö17, Ö19, } \\
\text { Ö21, Ö26, Ö27 }\end{array}$ & 9 & $\begin{array}{l}\text { Ö11, Ö28, } \\
\text { Ö31,Ö38,Ö41 }\end{array}$ \\
\hline $\begin{array}{l}\text { Maddi olanaklarının } \\
\text { yetersiz olması }\end{array}$ & $\begin{array}{l}\text { Ö4, Ö6, Ö10, } \\
\text { Ö21, Ö24,Ö30 }\end{array}$ & 6 & $\begin{array}{l}\text { Ö11, Ö28, Ö33, } \\
\text { Ö35,Ö40, Ö41,Ö42 }\end{array}$ \\
\hline $\begin{array}{l}\text { Çalışma şartlarının adil } \\
\text { olmaması }\end{array}$ & $\begin{array}{l}\text { Ö4,Ö8,Ö9,Ö10, } \\
\text { Ö21,Ö30, Ö32 }\end{array}$ & 7 & Ö11,Ö33,Ö41,Ö42 \\
\hline $\begin{array}{l}\text { Öğretmen yetiştirme } \\
\text { programlarının sürekli } \\
\text { değiştirilmesi }\end{array}$ & Ö5 & 1 & - \\
\hline $\begin{array}{l}\text { Lisans düzeyinde } \\
\text { verilen eğitimin teorik } \\
\text { olması }\end{array}$ & Ö5, Ö7,Ö8, Ö15 & 4 & $\begin{array}{l}\text { Ö14, Ö20, } \\
\text { Ö25,Ö31 }\end{array}$ \\
\hline
\end{tabular}

Tablo 2 incelendiğinde, öğretmen adaylarının öğretmenlik mesleğinin avantajlı yönlerinden çok (kızlar, $\mathrm{f}=21$, erkekler, $\mathrm{f}=19$ ) dezavantajlı yönlerine (kılar, $\mathrm{f}=45$, erkekler, $\mathrm{f}=35$ ) daha fazla vurgu yaptıkları anlaşılmıştır. Buna göre, öğretmen adaylarının öğretmenliğin "mesleki doyumunun yüksek olduğunu (kızlar, $\mathrm{f}=9$, erkekler, $\mathrm{f}=10$ ) ve çalışma saatlerinin uygun olduğunu (kızlar, $\mathrm{f}=12$; erkekler $\mathrm{f}=8$ ) düşündükleri; sadece bir erkek öğretmen adayının da (Ö1) “değişik yerleri görme imkânı sağlaması” sağlaması sebebiyle öğretmenlik mesleğini avantajlı bulduğu anlaşılmaktadır.

Dezavantajları konusunda öne sürdükleri görüşleri incelendiğinde, sınavla öğretmen ataması yapılıyor (kızlar, $\mathrm{f}=9$; erkekler, $\mathrm{f}=5$ ) "atamalar az (kızlar, $\mathrm{f}=7$; erkekler, $\mathrm{f}=5$ ), mezun sayısı çok (kızlar, $\mathrm{f}=2$; erkekler, $\mathrm{f}=1$ ) şeklinde eleştiriler getirdikleri tespit edilmiştir. Ayrıca öğretmenlik mesleğinin statüsü düşük (kızlar, $f=9$, erkekler, $f=9$ ), maddi olanaklarının yetersiz (kızlar, $\mathrm{f}=6$, erkekler, $\mathrm{f}=7$ ), çalışma şartları adil değil (kızlar, $\mathrm{f}=7$, erkekler, $f=4$ ), lisans düzeyinde verilen eğitimin teorik (kızlar, $f=4$; erkekler, $f=4$ ) şeklinde sebepler ileri sürdükleri tespit edilmiştir. Bir kız öğretmen adayının da (Ö5) Öğretmen yetiştirme programlarının sürekli değiştirilmesini eleştirdiği anlaşılmıştır. 
Oransal olarak değerlendirildiğinde (Şekil 2) kız öğretmen adaylarının öğretmenlik mesleğinin hem avantajları (\% 53) ve hem de dezavantajları (\%56) konusunda erkeklere (avantaj \%47, dezavantaj \% 44) kıyasla daha fazla görüş bildirdikleri anlaşılmıştır. Cinsiyetler kendi içinde değerlendirildiğinde erkek öğretmen adaylarının öğretmenlik mesleğinin avantajlarını, kız öğretmen adaylarının da dezavantajlarını daha fazla dile getirdikleri anlaşılmıştır. Aşağıda bazı öğretmen adaylarının avantaj ve dezavantajlar konusunda dile getirdikleri açıklamalarına yer verilmiştir.
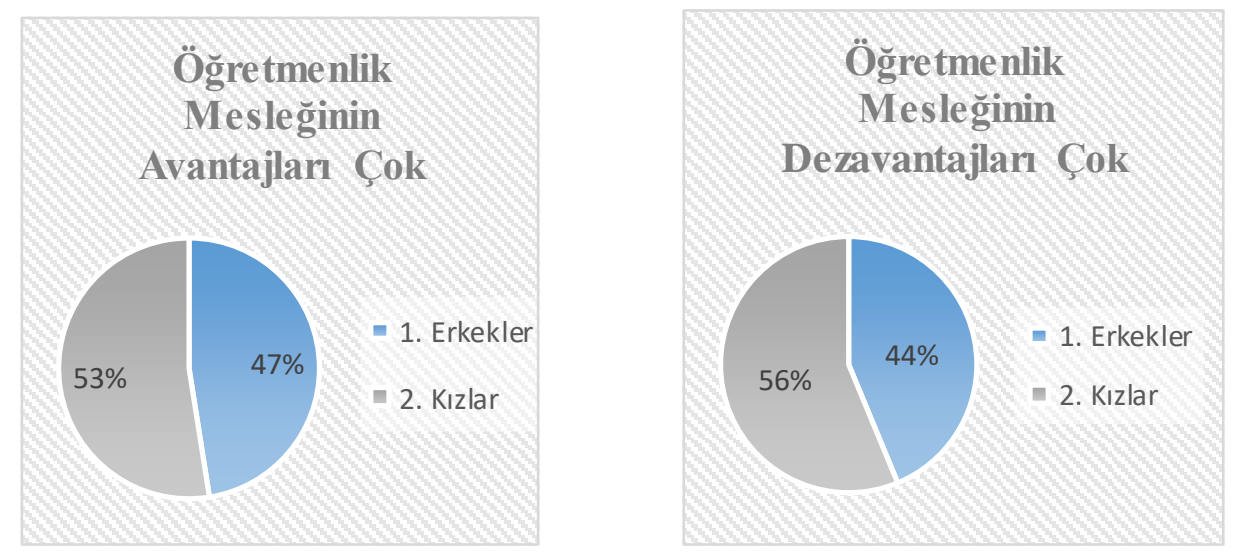

Şekil 2. Mesleğin avantajlarl/dezavantajları konusuna yönelik görüşler

“İlkokul öğretmenimi çok seviyordum. Çocuklarla da iyi anlaştı̆̆ım için bu mesleği yapabileceğimi düşünüyorum. Toplumsal saygınlık bakımından öğretmenlik mesleğini olumlu değerlendiriyorum. Kişi kendini geliştirdiği sürece bu meslek tatmin de săgllyor. Ancak mezun olduktan sonra, mesleği yerine getiremeyeceğimizi düşündüğümüz için atanamama kaygısı taşıyoruz. Sınav hazırlı̆̆ı yaptı̆̆ımız için, son sınıfta arkadaşlarımızla yeterince vakit geçiremiyoruz. Bizleri her alanda donatmaları, geliştirmeliler. Mezun olduktan sonra iş bulabilme garantisi vermeliler. Çalışma koşullarımızı iyileştirmeliler” Ö8

“Öğretmenlik çocuklarla sürekli ilgilenmeyi gerektirdiğinden zor bir meslek. Ayrıca köy okullarına atanabiliyorsunuz, zor şartlar altında çalışmak zorundasınız. Diğer mesleklerde bu tür bir uygulama yok. Ancak, çocuklara bir şeyler öğretebilmek, onları geleceğe hazırlayacak davranışlar ögretebilmek gibi avantajları da var.” Ö9

“Öğretmenlerin koşullarının iyileştirilmesi, maaşlarının artırılması, doktorların aldı̆̆ düzeye getirilmesi gerekir. Böylece sınavlarda en iyi puanı alan adaylar doktorluk gibi ögretmenliği de seçebilir. Zeki öğrenciler öğretmenlik mesleğini seçerse, nitelikli insanlar/bireyler yetiştirebilir" Ö11 
“Türkiye'de ögretmenliğe genel olarak rahat, çalışma saatleri az, kolay bir meslek gözüyle bakıllyor. Bu bakımdan doğru olsa da öğretmen olabilmek zor. Çünkü KPSS sınavı ve atamalarda sıkıntılar olması, ögretmen adaylarını meslekten soğutuyor. ” Ö26

\section{Ö̈̆retmenlik mesleğini seçme nedenleri (b)}

Öğretmen adaylarının mesleği seçme nedenleri dört alt boyutta incelenmiştir (Tablo 3).

Tablo 3. Öğretmenlik mesleğini seçme nedenleri

\begin{tabular}{llclc}
\hline $\begin{array}{l}\text { Öğretmenlik mesleğini } \\
\text { seçme nedenleri }\end{array}$ & Kadın & $\begin{array}{c}\text { Frekans } \\
(\mathbf{f})\end{array}$ & Erkek & $\begin{array}{c}\text { Frekans } \\
\text { (f) }\end{array}$ \\
\hline $\begin{array}{l}\text { Sinav puanının öğretmen } \\
\text { olmaya yetmesi }\end{array}$ & $\begin{array}{l}\text { Ö9, Ö17, } \\
\text { Ö24,Ö30,Ö32 }\end{array}$ & $\mathbf{5}$ & $\begin{array}{l}\text { Ö1, Ö11, Ö14, } \\
\text { Ö22, Ö28, } \\
\text { Ö36,Ö42 }\end{array}$ \\
Ailesi öğretmen olmasın1 & Ö2, Ö3, Ö5, Ö17, & $\mathbf{5}$ & Ö20, Ö22, \\
istemesi & Ö26,Ö30, Ö32 & & Ö25,Ö35,Ö39 & \\
Öğretmenlik mesleğinin & Ö3,Ö4,Ö5,Ö6,Ö7, & $\mathbf{1 4}$ & Ö1, Ö11, Ö13, \\
kişilik özelliklerine & Ö8,Ö9,Ö12,Ö15, & & Ö14, Ö18, Ö25, \\
uygun olduğunu & Ö19,Ö21,Ö23,Ö24 & & Ö29,Ö33,Ö34,Ö37, \\
düşünmesi & Ö26,Ö27 & Ö38,Ö40,Ö41 & \\
Topluma yararl1 olmak & Ö6, Ö7, Ö16, Ö19, & $\mathbf{7}$ & Ö1,Ö18,Ö33,Ö35, & $\mathbf{7}$ \\
istemesi & Ö23, Ö27,Ö30 & & Ö36,Ö37,Ö38 \\
\hline
\end{tabular}

Tablo 3'te görüldüğü gibi, öğretmen adayları, çoğunlukla (kızlar f=14, erkekler f=13) “öğretmenliği kişilik özelliklerine uygun bulduğu”, "topluma yararlı olmak istediği”" (kızlar $\mathrm{f}=7$, erkekler $\mathrm{f}=7$ ) ve "ailesi öğretmen olmasını beklediği" (kızlar $\mathrm{f}=5$, erkekler, $\mathrm{f}=5$ ) için öğretmenlik mesleğini seçmeyi uygun bulmaktadır. Bu sonuçlara bakılarak öğretmen adaylarının, kişiliğine uygun olduğunu düşünerek, üniversite sınavlarında alınan puanlara bakarak, topluma faydalı olabileceğini göz önünde bulundurarak ve ailesinin yönlendirmelerini dikkate alarak öğretmenlik mesleğini seçme kararı aldıkları söylenebilir. Şekil 3'de "kızlar gri, erkekler mavi renk" renkle gösterilmiş, öğretmen adaylarının öğretmenlik mesleğini tercih etme nedenleri incelenmiştir. 


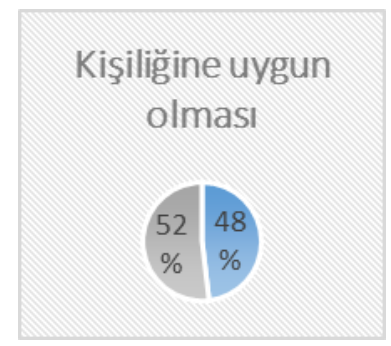

Toplumsal Fayda

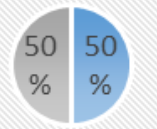

Sınav

puanı

Şekil 3. Öğretmen adaylarının öğretmenlik mesleğini seçme nedenleri

Şekil 3'de oransal olarak değerlendirildiğinde; kız öğretmen adaylarının öncelikle kişilik özelliklerine uygun olması sebebiyle, öğretmenlik mesleğini tercih ettiği (\% 52), toplumsal fayda (\%50) ve aile isteğini (\%50) ikinci planda tuttukları ve son olarak sınav puanı yeterli olduğu için (\%42) öğretmenlik programına kayıt olmayı tercih ettikleri anlaşılmaktadır. Erkek öğretmen adaylarının da, toplumsal fayda (\%50) ve aile isteğini (\%50) eşit oranda değerlendirdiği, ancak daha çok sınav puanının yetmesinin (\%58) sebebiyle öğretmenlik programına kayıt yaptırdığı anlaşılmaktadır. Kızlarla kıyaslandığında erkek öğretmen (\%48) adaylarının kişiliğ̈ine uygun olmasını öncelikli değerlendirmediği anlaşılmaktadır. Aşağıda bazı öğretmen adaylarının bu konuda yaptıkları açıklamalardan alıntılar sunulmuştur.

"Kalplere dokunan hayatı değiştiren başka bir meslek düşünemiyorum. Kendimi de öğretmenlik mesleği dışında başka bir meslekte hayal edemiyorum. " Ö8

"Sinav puanıma en uygun bölüm ögretmenlik olduğu için bu mesleği seçtim. Ayrıca çalışma saatlerinin uygun olması sebebiyle (bir bayan olarak) öğretmenlik mesleğinin bana uygun olduğunu düşündüm." Ö9

"Çocukluğun köyde geçti. Doğal olarak köy okuluna gittim. Liseyi ise ilçedeki ögrretmen okulunda okudum. Lisede derslere fazla önem vermediğim için sinavlardan istediğim puanı alamadım. Öncelikle puanım buraya yetti. Puanım yüksek olsaydı büyük ihtimalle bu bölümde değildim. Ancak bu demek değil ki bölümden memnun değilim. Iyi bir ögrretmen olacağıma inaniyorum." Ö11

"Öğretmen lisesi mezunuyum. Karakterime en uygun meslek olduğu için seçtim. Rehberlik servisindeki ögrretmenlerimle konuşup, bu konuda karar kıldım. Öğretmenliğin maddi getirisi için seçilmemeli. Gençler ilgileri ve yetenekleri de değerlendirilerek bu mesleğe yönlendirilmeliler." Ö18

"Çocuklart sevmem ve çocuklara bir şeyleri öğretmeyi sevmem bu mesleği seçme nedenim. Öğretmenlik kutsal bir meslektir. Bireyin yetiştirilmesinde aileden sonra en önemli 
kişi ögretmenlerdir. Daha güzel bir dünya için, insanlığın donanımll, idealist öğretmenlere ihtiyacı var. Çünkü insanlık değerlerinin doğru bir şekilde kazandırılmasında öğretmenlerin büyük rolü var." Ö27

\section{Öğretmen adaylarının geleceğe yönelik beklentileri}

İkinci temada öğretmen adaylarının geleceğe yönelik beklentileri "mevcut olanaklar ölçüsünde öğretmen mesleğini tercih etme noktasında beklentileri ve her türlü imkân sunulsa yapmak/değiştirmek istedikleri (kendi gerçekliğiyle yüzleşme)" olmak üzere iki alt boyutta incelenmiştir (Tablo 4).

\section{Öğretmenlik mesleğini tercih etme noktasında beklentileri (Mevcut olanaklar ölçüsünde)}

İlk tur görüşmelerde öğretmen adaylarının mevcut olanaklar ölçüsünde öğretmenlik mesleğini seçme/tercih etme konusunda ne tür beklentileri olduğu anlaş1lmaya çalışmıştır. Öğretmen adaylarının açıklamaları incelendiğinde mesleğe atanmadan (hizmet öncesi) ve mesleğe atıldıktan sonra (hizmet içi) bazı beklentileri olduğu anlaşılmıştır (Tablo 4).

Tablo 4. Öğretmenlik mesleğini seçme noktasında beklentileri

\begin{tabular}{llclc}
\hline Beklentileri & Kadın & Frekans (f) & Erkek & Frekans (f) \\
\hline Hizmet öncesi & & $\mathbf{3 5}$ & & $\mathbf{3 1}$ \\
\hline $\begin{array}{l}\text { Eğitim fakülte kontenjanları } \\
\text { ile atamalar orantılı bir }\end{array}$ & Ö8, Ö7, Ö30 & $\mathbf{4}$ & Ö1, Ö29, Ö31, & $\mathbf{4}$ \\
$\begin{array}{l}\text { şekilde düzenlenmeli } \\
\text { KPSS sınav1 tek oturum }\end{array}$ & Ö4 & Ö33 & \\
$\begin{array}{l}\text { halinde yapılmalı } \\
\text { Öğretmen atamalarında }\end{array}$ & Ö3, Ö7, Ö8, Ö9, & $\mathbf{9}$ & Ö1, Ö11, Ö18, & $\mathbf{7}$ \\
$\begin{array}{l}\text { KPSS sınav sistemine son } \\
\text { verilmeli }\end{array}$ & Ö15, Ö21, Ö26, & & Ö25, Ö29, & \\
$\begin{array}{l}\text { Öğretmen seçiminde kişisel } \\
\text { özelliklere bak1lmal1 }\end{array}$ & 27, Ö32 & & Ö38, Ö41 & \\
$\begin{array}{l}\text { Öğretmen yetiştiren } \\
\text { kurumları değerler }\end{array}$ & Ö4 & $\mathbf{2}$ & Ö18, Ö29 & $\mathbf{2}$ \\
$\begin{array}{l}\text { eğitimine önem vermeli } \\
\text { Öğretmen yetiştiren } \\
\text { kurumlar teorik değil }\end{array}$ & Ö5, Ö7, Ö8, & $\mathbf{4} 15$ & Ö14, Ö20, Ö25 & $\mathbf{3}$ \\
uygulamaya dayalı eğitim & & $\mathbf{1}$ & Ö14, Ö18,Ö29 & $\mathbf{3}$ \\
& & & &
\end{tabular}


vermeli

Mesleğini layıkıyla yerine

Ö2, Ö5, Ö7, Ö8,
Ö10, Ö12, Ö15,
Ö17, Ö24,
Ö27,Ö32

12

Ö1, Ö11, Ö14,

getirebilecek öğretmenler

Ö17, Ö24,

Ö18, Ö20, Ö22,

yetiştirilmeli

$$
\text { Ö27,Ö32 }
$$

Ö25, Ö29, Ö33,

Ö36, Ö37, Ö40

Meslek seçiminde gençlerin Ö2,Ö6

2

tercihlerine ve fikirlerine

sayg1 duyulmalı

\begin{tabular}{llllc}
\hline Hizmet içi & \multicolumn{2}{c}{$\mathbf{2 0}$} & $\mathbf{1 5}$ \\
\hline Öğretmenlerin çalışma & Ö8, Ö17, & $\mathbf{4}$ & Ö11, Ö18, Ö38, & $\mathbf{5}$ \\
koşullar1 iyileştirilmeli & Ö30,Ö32 & & Ö41, Ö42 \\
Öğretmenlerin gelir & Ö4,Ö6,Ö15,Ö17 & $\mathbf{7}$ & Ö11, Ö14, Ö28, & $\mathbf{5}$ \\
seviyesi yükseltilmeli & Ö21, Ö24, Ö30 & & Ö41,Ö42 \\
Öğretmenlik mesleğinin & Ö7, Ö8, Ö9, & $\mathbf{9}$ & Ö13, Ö18, Ö20, & $\mathbf{5}$ \\
saygınlığ1 yükseltilmeli & Ö10, Ö17, Ö19, & & Ö28, Ö29, \\
& Ö21,Ö30,Ö32 & & Ö33,Ö41 \\
\hline
\end{tabular}

Tablo 4’te görülebileceği gibi öğretmen adaylarının hizmet öncesi dönemde öğretmenlik mesleğini seçebilmeleri yönünde daha fazla beklenti içinde oldukları görülmektedir. Mesleği tercih edebilmeleri için öğretmen adaylarının, en fazla (kızlar, f=12; erkekler, $\mathrm{f}=12$ ) “öğretmenlik mesleğini layıkıyla yerine getirebilecek öğretmenler yetiştirilmeli” şeklinde beklenti içinde oldukları anlaşılmaktadır. Sonra sırasıyla; "öğretmen atamalarında KPSS sınav sistemine son verilmeli (kızlar, $\mathrm{f}=9$; erkekler, $\mathrm{f}=7$ ); eğitim fakülteleri kontenjanları ile atamalar orantılı bir şekilde düzenlenmeli (kızlar, $\mathrm{f}=4$; erkekler, $\mathrm{f}=4$ ); öğretmen yetiştiren kurumlar teorik değil uygulamaya dayalı eğitim vermeli (kızlar, $\mathrm{f}=4$; erkekler, $\mathrm{f}=3$ ); öğretmen seçiminde kişisel özelliklere bakılmalı (kızlar, $\mathrm{f}=2$; erkekler, $\mathrm{f}=2$ ), ve öğretmen yetiştiren kurumlar değerler eğitimine önem vermeli (kızlar, $\mathrm{f}=1$; erkekler, $\mathrm{f}=3$ )" şeklinde görüşlerini iletmişlerdir. Bu konulardan farklı olarak bir kız öğretmen adayının (Ö4), "KPSS sınavı tek oturum halinde yapılmalı”; iki kız öğretmen adayının da (Ö2,Ö6) "meslek seçiminde gençlerin tercihlerine ve fikirlerine sayg1 duyulmalı" şeklinde beklenti içinde oldukları belirlenmiştir.

Göreve başladıktan sonra da (hizmet içi) gerçekleşmesini istediklerin şeylerin başında en fazla öğretmenlik mesleğinin saygınlığının (kızlar, f=9; erkekler, f=5), ikinci olarak öğretmenlerin gelir seviyesinin yükseltilmesini (kızlar, $f=7$; erkekler, $f=5$ ) ve üçüncü 
olarak öğretmenlerin çalışma koşullarının iyileştirilmesini (kızlar, $\mathrm{f}=4$; erkekler, $\mathrm{f}=5$ ) istedikleri anlaşılmaktadır.

Ancak oransal büyüklüklerine bakıldığında sonuçlar; kız öğretmen adaylarının (hizmet \% 52, göreve başladıktan sonra:\%57); erkek öğretmen adaylarına (hizmet öncesi: \%48 ve göreve başladıktan sonra:\% 43) kıyasla daha fazla beklentiler içinde olduğu görülmektedir. Bununla birlikte cinsiyetler kendi içinde değerlendirildiğinde erkek öğretmen adaylarının (\%48) göreve başlamadan önce; kız öğretmen adaylarının da göreve başladıktan sonra (\%57) taleplerinin daha yüksek olduğu anlaşılmaktadır (Şekil 4).
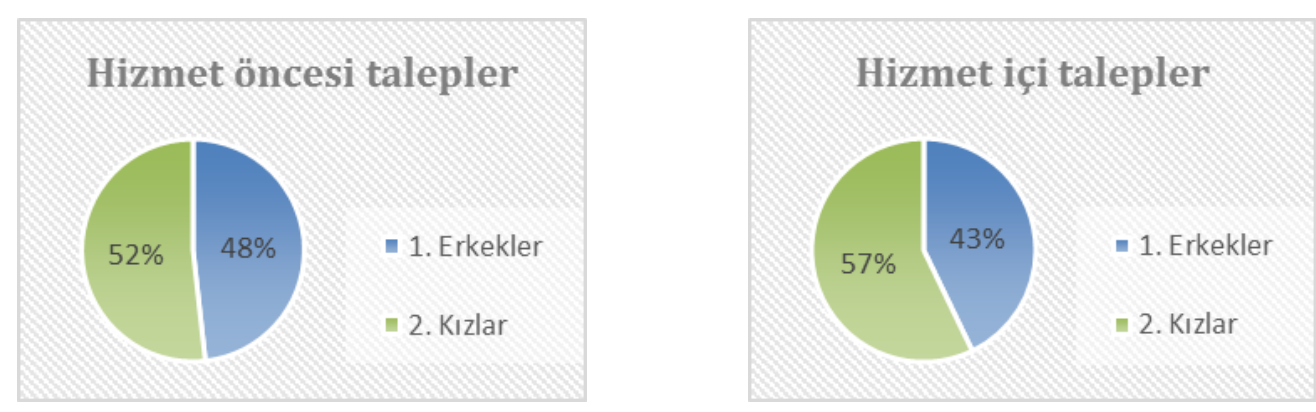

Şekil 4. Ö̆̆retmen adaylarının hizmet öncesi ve hizmet sonrası talepleri

Aşağıda öğretmenlik mesleğini seçme ve beklentiler noktasında bazı öğretmen adaylarının yaptıkları açıklamalardan alıntılar sunulmuştur.

"KPSS sinavı olmadan ögretmen olarak atanmak isterdim. Fakültede daha fazla uygulamalı dersler olsun isterim. Görev yaptıkları süre içinde karşılaşabilecekleri zorluklar konusunda destekler sunulsun isterim. Iyi bir öğretmen olmak, farkındalık yaratmak, bir şeyleri değiştirmek istiyorum. ” Ö8

"Programda teorik dersleri azaltıp, uygulamalı derslerin artırılması, mesleğin cazip hale getirilmesi." Ö20

"İhtiyaca göre üniversitelere ögrenci yetiştirilmeli ve mezun olduktan sonra iş garantisi olmall. Öğretmenliğe gereken önem verilmeli. Bu mesleği gerçekten seven ve bu mesleğin önemini kavrayan farkında olan insanlar atanmalı.” Ö29

“Öğretmenlerin de en az hukuk ve tıp kadar hak ettiği yere gelmesi lazım. Hatta ögretmen ĕgitimi konusuna ĕgitime önem verilmeli. Süre ve nitelik açısından iyileştirmeler yapılmalı. Örneğin Finlandiya'da öğretmen eğitiminin süresi 8 yılken, Türkiye'de 4 yıl olmasl, öğretmenlik ĕgitimine önem vermediğimizin göstergesidir. ” Ö32 


\section{Olanaklar mümkün olsa hayattan beklentileri (her türlü olanaklar sunulsa yapmak/değiştirmek istedikleri: kendi gerçekliğiyle yüzleşme) (b)}

Bu başlıkta da "İstediğiniz kadar paranız olsaydı ne yapardınız?" ve "Masallardaki gibi bir peri ‘dile benden ne dilersen' deseydi, en önemli üç dileğiniz ne olurdu?” sorularına verilen cevaplar "bireysel hedefler”; "Her türlü olanağınız bulunsa hangi mesleği seçmek isterdiniz?" ve "Öğretmenlik mesleğinde mutlu olabilmeniz için nelerin değişmesini isterdiniz?" sorularına verilen cevaplar da "mesleki hedefler" bağlamında değerlendirilmiştir (Tablo 5).

Tablo 5. Her türlü olanaklar sunulsa yapmak/değiştirmek istedikleri

\begin{tabular}{|c|c|c|c|c|}
\hline İstekler & Kadın & Frekans (f) & Erkek & Frekans (f) \\
\hline Bireysel açıdan & & 55 & & 39 \\
\hline $\begin{array}{l}\text { Ailesini mutlu etmek } \\
\text { (maddi/manevi anlamda) }\end{array}$ & $\begin{array}{l}\text { Ö2, Ö3, Ö5, } \\
\text { Ö7, Ö10, Ö16, } \\
\text { Ö17, Ö21, Ö30 }\end{array}$ & 9 & $\begin{array}{l}\text { Ö11, Ö13, Ö18, } \\
\text { Ö22, Ö34, Ö35, } \\
\text { Ö36, Ö40 }\end{array}$ & 8 \\
\hline $\begin{array}{l}\text { Yaşadığ1 yeri (ülkeyi/şehri) } \\
\text { değiştirmek }\end{array}$ & $\begin{array}{l}\text { Ö2, Ö5, Ö15, } \\
\text { Ö16, Ö19, Ö27 }\end{array}$ & 6 & - & - \\
\hline $\begin{array}{l}\text { Farklı konularda öğrenim } \\
\text { görmek/kendini geliştirmek }\end{array}$ & $\begin{array}{l}\text { Ö3, Ö6, Ö16, } \\
\text { Ö23, Ö26,Ö30 }\end{array}$ & 6 & $\begin{array}{l}\text { Ö1, Ö20, Ö25, } \\
\text { Ö35 }\end{array}$ & 4 \\
\hline $\begin{array}{l}\text { Başka insanlara yardımcı } \\
\text { olmak (maddi/manevi) }\end{array}$ & $\begin{array}{l}\text { Ö3, Ö4, Ö7, } \\
\text { Ö8, Ö15, Ö16, } \\
\text { Ö17, Ö23,Ö30 }\end{array}$ & 8 & $\begin{array}{l}\text { Ö11, Ö18, Ö29, } \\
\text { Ö33, Ö35, Ö37, } \\
\text { Ö40, Ö42 }\end{array}$ & 8 \\
\hline $\begin{array}{l}\text { Kişilik özelliklerini } \\
\text { değiştirmek }\end{array}$ & $\begin{array}{l}\text { Ö3, Ö4, Ö8, } \\
\text { Ö10, Ö15, Ö26 }\end{array}$ & 6 & - & - \\
\hline $\begin{array}{l}\text { Fiziksel özelliklerini } \\
\text { değiştirmek }\end{array}$ & Ö19, Ö27,Ö30 & 3 & $\begin{array}{l}\text { Ö11, Ö14, Ö18, } \\
\text { Ö29 }\end{array}$ & 4 \\
\hline $\begin{array}{l}\text { Bireysel ihtiyaçlarını } \\
\text { karşılamak }\end{array}$ & $\begin{array}{l}\text { Ö5,Ö7,Ö9,Ö10 } \\
\text { Ö12, Ö15,Ö19, } \\
\text { Ö21, Ö23,Ö26, } \\
\text { Ö27 }\end{array}$ & 11 & $\begin{array}{l}\text { Ö11, Ö18, Ö22, } \\
\text { Ö29, Ö33, Ö34, } \\
\text { Ö35,Ö36,Ö41 }\end{array}$ & 9 \\
\hline Adil bir dünyada yaşamak & $\begin{array}{l}\text { Ö5, Ö7, Ö8, } \\
\text { Ö24,Ö30, Ö32 }\end{array}$ & 6 & $\begin{array}{l}\text { Ö14, Ö25, Ö29, } \\
\text { Ö31,Ö41, Ö42 }\end{array}$ & 6 \\
\hline Dünyayı dolaşmak & $\begin{array}{l}\text { Ö6, Ö16, Ö19, } \\
\text { Ö21, Ö23,Ö32 }\end{array}$ & 6 & - & - \\
\hline
\end{tabular}




\begin{tabular}{|c|c|c|c|c|}
\hline Meslek seçimi açısından & & 61 & & 56 \\
\hline Sevebileceği işi yapmak & $\begin{array}{l}\text { Ö2,Ö3,Ö4,Ö6, } \\
\text { Ö12, Ö15,Ö16, } \\
\text { Ö17, Ö21,Ö23, } \\
\text { Ö24, Ö26,Ö30, } \\
\text { Ö32 }\end{array}$ & 14 & $\begin{array}{l}\text { Ö1, Ö18, Ö20, } \\
\text { Ö22,Ö25,Ö29, } \\
\text { Ö31,Ö35,Ö36, } \\
\text { Ö40,Ö41 Ö42 }\end{array}$ & 12 \\
\hline $\begin{array}{l}\text { Ekonomik anlamda getirisi } \\
\text { yüksek bir iş sahibi olmak }\end{array}$ & $\begin{array}{l}\text { Ö4, Ö23, } \\
\text { Ö24,Ö30, }\end{array}$ & 4 & $\begin{array}{l}\text { Ö11, Ö25, Ö27, } \\
\text { Ö29, Ö36, Ö37 } \\
\text { Ö42 }\end{array}$ & 7 \\
\hline $\begin{array}{l}\text { Statüsü yüksek bir iş sahibi } \\
\text { olmak }\end{array}$ & Ö15, Ö32 & 2 & Ö24, Ö33, Ö40 & 3 \\
\hline Kendi işini kurmak & $\begin{array}{l}\text { Ö2, Ö4, Ö19, } \\
\text { Ö23, Ö24, } \\
\text { Ö27,Ö30 }\end{array}$ & 7 & $\begin{array}{l}\text { Ö1, Ö11, Ö18, } \\
\text { Ö20,Ö29, Ö37, } \\
\text { Ö41, Ö42 }\end{array}$ & 8 \\
\hline $\begin{array}{l}\text { Yetersiz öğretmenlerin işine } \\
\text { son verilmesi/emekli } \\
\text { edilmesi }\end{array}$ & Ö12 & 1 & Ö39 & 1 \\
\hline $\begin{array}{l}\text { Öğretmenlerin mesleki } \\
\text { standartlarının yükseltilmesi }\end{array}$ & Ö12, Ö21,Ö30 & 3 & $\begin{array}{l}\text { Ö20, Ö40, Ö41, } \\
\text { Ö42 }\end{array}$ & 4 \\
\hline $\begin{array}{l}\text { Öğretmenlerin gelirlerinin } \\
\text { artırılması }\end{array}$ & Ö6, Ö30 & 2 & Ö24, Ö41, Ö42 & 3 \\
\hline $\begin{array}{l}\text { Öğretmenlik mesleğine } \\
\text { daha fazla değer verilmesi }\end{array}$ & Ö7, Ö9, 019 & 3 & - & - \\
\hline $\begin{array}{l}\text { Öğretmenlik mesleğini } \\
\text { herkesin severek yapması }\end{array}$ & & & Ö31 & 1 \\
\hline KPSS sınavının kalkması & $\begin{array}{l}\text { Ö3, Ö7, Ö8, } \\
\text { Ö9, Ö10, Ö15, } \\
\text { Ö21, Ö24, Ö26 }\end{array}$ & 9 & $\begin{array}{l}\text { Ö1,Ö11, Ö14, } \\
\text { Ö25, Ö29, Ö31, } \\
\text { Ö38 }\end{array}$ & 7 \\
\hline $\begin{array}{l}\text { Okulların durumunun } \\
\text { iyileştirilmesi }\end{array}$ & Ö7, Ö21,Ö30 & 3 & Ö42 & 1 \\
\hline $\begin{array}{l}\text { Eğitim yerlerinin sevgi } \\
\text { yerlerine dönüştürülmesi }\end{array}$ & Ö4 & 1 & - & - \\
\hline Atamaların yapılmasını & Ö26, Ö27, Ö32 & 3 & Ö31,Ö41 & 2 \\
\hline
\end{tabular}


sağlamak

Herkesin kendi

memleketine atanmas1

Herkesin eşit/adil eğitim

almasını sağlamak
Ö23

$$
\begin{aligned}
& \text { Ö5, Ö7, Ö8, } \\
& \text { Ö16, Ö17,Ö23, } \\
& \text { Ö24, Ö32 }
\end{aligned}
$$

1

$8 \begin{aligned} & \text { Ö20, Ö31, Ö33, } \\ & \text { Ö34, Ö36, Ö40, } \\ & \text { Ö41 }\end{aligned}$

Tablo 5'te görülebileceği gibi, öğretmen adaylarının bireysel olarak en çok isteği şeyin ihtiyaçlarını karşılamak (kızlar, $\mathrm{f}=11$; erkekler, $\mathrm{f}=9$ ), ikinci olarak ailesini mutlu etmek (kızlar, $\mathrm{f}=9$; erkekler, $\mathrm{f}=8$ ), üçüncü olarak başka insanlara yardımcı olmak (kızlar, $\mathrm{f}=8$; erkekler, $f=8$ ), dördüncü olarak adil bir dünyada yaşamak (kızlar, $f=6$; erkekler, $f=6$ ), beşinci olarak farklı konularda öğrenim görmek/kendini geliştirmek (kızlar, $\mathrm{f}=6$; erkekler, $\mathrm{f}=4$ ), altıncı olarak ise fiziksel özelliklerini değiştirmek (kızlar, $f=3$; erkekler, $f=4$ ) olduğu anlaşılmıştır. Erkeklerden farklı olarak bazı kız öğretmen adaylarının, yaşadığı yeri (ülkeyi/şehri) değiştirmek (Ö2, Ö5, Ö15, Ö16, Ö19, Ö27), kişilik özelliklerini değiştirmek (Ö3, Ö4, Ö8, Ö10, Ö15,Ö26) ve dünyay1 dolaşmak (Ö6, Ö16, Ö19, Ö21, Ö23, Ö32) gibi farklı arzularının olduğu belirlenmiştir.

Olanaklar mümkün olsa (düş/hayal), mesleki açıdan gerçekleşmesini istedikleri hayallerine bakıldığında, sevebileceği işi yapmak (kızlar, $\mathrm{f}=12$; erkekler, $\mathrm{f}=12$ ), kendi işini kurmak (kızlar, $\mathrm{f}=7$; erkekler, $\mathrm{f}=8$ ) ekonomik anlamda getirisi yüksek bir iş sahibi olmak (kızlar, $\mathrm{f}=4$; erkekler, $\mathrm{f}=7$ ), statüsü yüksek bir iş sahibi olmak (kızlar, $\mathrm{f}=2$; erkekler, $\mathrm{f}=3$ ) gibi beklentiler içine girdikleri anlaşılmaktadır. $\mathrm{Bu}$ bulgular bazı öğretmen adaylarının hayallerinde olmak istediği mesleği seçemeyip mevcut şartlara göre karar vermek durumunda kaldıklarını göstermektedir.

“Öğretmenlik mesleğinde mutlu olabilmeniz için nelerin değişmesini isterdiniz?” sorusuna verilen cevaplarda öğretmen adaylarının, KPSS sınavının kalkması (kızlar, f=9; erkekler, $f=7$ ), herkesin eşit/adil eğitim alması (kızlar, $f=; 8$ erkekler, $f=7$ ), öğretmenlerin mesleki standartlarının yükseltilmesi (kızlar, $\mathrm{f}=3$; erkekler, $\mathrm{f}=4$ ) öğretmenlerin gelirlerinin artırılması (kızlar, $\mathrm{f}=2$; erkekler, $\mathrm{f}=3$ ), okulların durumunun iyileştirilmesi (kızlar, $\mathrm{f}=3$; erkekler, $\mathrm{f}=1$ ); atamaların yapılması (kılar, $\mathrm{f}=3$; erkekler, $\mathrm{f}=2$ ); yetersiz olan öğretmenlerin işine son verilmesi/emekli edilmesi, (kızlar, $\mathrm{f}=1$; erkekler, $\mathrm{f}=1$ ) gibi istekleri olduğu anlaşılmaktadır. Bunun dışında üç kız öğretmen adayının (Ö7, Ö9, 019) öğretmenlik mesleğine daha fazla değer verilmesi, birer kız öğretmen adayının eğitim yerlerinin sevgi yerlerine dönüşmesi (Ö4) ve herkesin kendi memleketine atanması (Ö23) yönünde istekleri 
olduğu belirlenmiştir. Sadece bir erkek öğretmen adayının da (Ö31) öğretmenlik mesleğini herkesin severek yapması yönünde arzusu olduğu anlaşılmıştır.
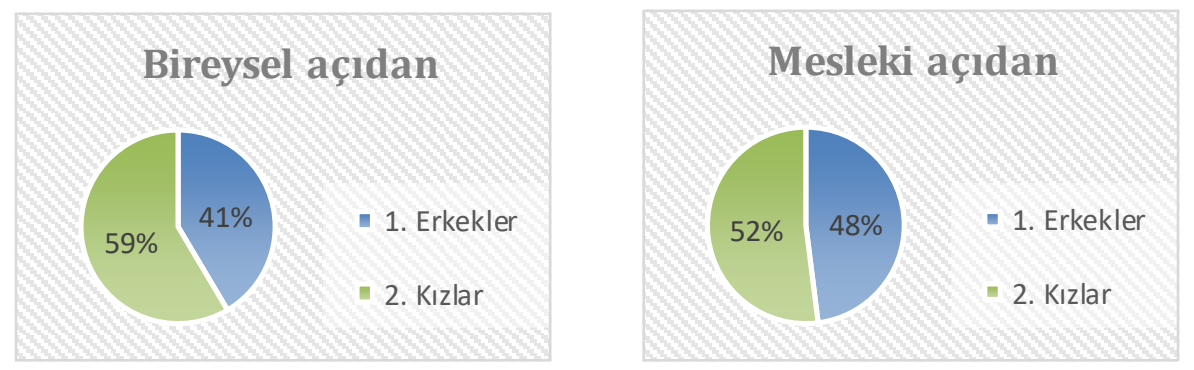

Şekil 5. Öğretmen adaylarının olanaklar sunulmuş olsa arzu ettiği şeyler

Şekil 5'te de görülebileceği gibi, olanaklar sunulmuş olsa kız öğretmen adaylarının bireysel arzularının (\%59) ve mesleki arzularının (\%52) erkek öğrencilere (bireysel \%41, mesleki, \%42) oranla daha fazla olduğu ve hayattan beklentilerinin daha yüksek olduğu anlaşılmaktadır. Cinsiyetler kendi içinde değerlendirildiğinde, kızların bireysel anlamda, erkek öğretmen adaylarının mesleki anlamda, arzu ettikleri şeylerin oransal olarak daha yüksek olduğu anlaşılmıştır. Aşağıda alıntılar sunulmuştur.

"Sadece kitapların olduğu bir dükkân sahibi olmak ve satmak isterdim. Yani esnaf olmak isterdim. Karakter olarak duygusal biriyim. Imkânım olsa yakınlarımı mutlu etmek isterim. Bisiklet ve oltamı alıp, sakin bir deniz kasabasında yaşamak isterdim. ” Ö18

"Yaşadığım yeri değiştirmek isterim. Atama yerlerinin değişmesini herkesin kendi

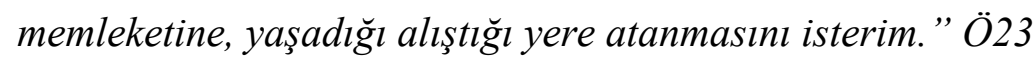

“Öğretmen olmak istiyorum ancak, imkânım olsa, özel bir okulda istediğim bölümü seçerdim. Psikolog olurdum. Öğretmenliği istemediğim için değil, psikolog olmayı çok istediğim için. Okul sonrası iş bulma zorunluğunun ortadan kalkmasını isterdim. KPSS gibi bir zorunluluk olması, ögretmen adaylarını mutlu değil, bezgin hissettiriyor. Sürekli plan yapıp, bu planlar yapmamak için güzel bahaneler üretmek gibi bir özelliğim var. Bu özelliğimi değiştirmek isterdim.” Ö26

“Muğla sınıf ögretmenliği bölümünü seçtim. Bu seçimimi yapmamdaki amacım tıpkı eski sınıf ögretmenim gibi olmak ve ideallerimi gerçekleştirmek demek isterdim ama maalesef değil. Üniversitenin ilk iki senesi açıkçası hala kendimi bu bölüme uygun hissetmiyordum. Teorik dersler sürekli ödev veren ögretmenler bana çok sıkıcı geldi. Uygulama dersleri bana ilaç gibi geldi. Staj ise benim dönüm noktam oldu. Öğretmenlik meslĕgini hissettim ve bana uygun olduğunu düşünmeye başladım. Beden Eğitimi, Fen 
Öğretimi, Görsel Sanatlar Ĕ̌itimi gibi uygulamalı derslerin düşünlerimi değiştirmemde katkısı oldu. Ancak imkânım olsa avukat olmayı seçerdim. " Ö32

\section{Tartışma ve Sonuç}

Nitel araştırma yaklaşımının benimsendiği bu araştırmada sınıf öğretmenliği son sınıfta okuyan öğretmen adaylarının öğretmenlik mesleği konusundaki düşünceleri, öğretmenlik mesleğini tercih etme sebepleri, öğretmenlik mesleğine yönelik beklentileri ve olanaklar mümkün olsa hayatta olmasını istedikleri şeylerin neler olduğu anlaşılmaya çalışılmıştır. Araştırmadan elde edilen sonuçlar "öğretmen adaylarının öğretmenlik mesleğine ilişkin görüşleri ve geleceğe yönelik beklentileri” olmak üzere iki temada değerlendirilmiştir.

Öğretmenlik mesleği sorumluluk ve fedakârlık gerektiren bir meslektir (Özbek, Kahyaoğlu ve Özgen, 2007). Bireyin içinde bulunduğu şartlar kaygı düzeyinin artmasına ve umutsuz olmalarına neden olabilmektedir (Poch, Esperanza, Villar vd., 2004). Mezuniyet sonrası istihdam, bireyi mesleğe yönlendiren koşullar ile mesleki anlamda zorlayan şartların incelenmesi (Williams ve Forgasz, 2009) adayların öğretmenlik mesleğini cazip bulacak koşullar yaratılması anlamında fikir verebilir. Bu çalışmada öğretmen adaylarının fedakârlık ve sorumluluk gerektiren bir meslek olarak tanımladıkları mesleğin avantajlı yönlerinden çok dezavantajlı yönlerine vurgu yaptıkları anlaşılmıştır. Avantajlı bulma sebeplerine bakıldığında, öğretmen adaylarının, öğretmenliğin mesleki doyumunun yüksek olduğunu ve çalışma saatlerinin uygun olduğunu düşündükleri belirlenmiştir. Sadece bir erkek öğretmen adayının da "değişik yerleri görme imkânı sağlaması" sağlaması sebebiyle öğretmenlik mesleğini avantajlı bulduğu tespit edilmiştir. Dezavantajları konusunda "sınavla öğretmen ataması yapılıyor, atamalar az, mezun sayısı çok" şeklinde eleştiriler getirdikleri ve “öğretmenlik mesleğinin statüsü düşük, maddi olanakları yetersiz, çalışma şartları adil değil, lisans düzeyinde verilen eğitim teorik” şeklinde görüşler ilettikleri tespit edilmiştir.

Hacıömeroğlu ve Taşkın (2010) ve Ubuz ve Sarı (2008) kişilik özelliklerinin öğretmenlik mesleğini tercih etmede önemli olduğunu, çocukları ve öğretmeyi sevdiğini söyleyen öğretmen adaylarının öğretmenlik mesleğini seçmeyi uygun bulduğunu belirlemişlerdir. Tataroğlu, Özgen ve Alkan (2011), Boz ve Boz (2008) öğretmen adaylarının öğretmenlik mesleğini tercih etme nedenleri arasında çocukluk öğretmeni sevme ve seçtikleri alanı sevme olarak belirttikleri anlaşılmıştır.

Oransal olarak değerlendirildiğinde kız öğretmen adaylarının öğretmenlik mesleğinin hem avantajları (\% 53) ve hem de dezavantajları (\%56) konusunda erkeklere (avantaj \%47, 
dezavantaj \% 44) kıyasla daha fazla görüş bildirdikleri anlaşılmıştır. Cinsiyetler kendi içinde değerlendirildiğinde erkek öğretmen adaylarının öğretmenlik mesleğinin avantajlarını, kız öğretmen adaylarının da dezavantajlarını daha fazla dile getirdikleri anlaşılmıştır. Nayır ve Taneri (2013) de kadın öğretmen adaylarının mesleği seçme nedenleri arasında kişisel özelliklerin ilk sırada geldiğini, kararlarında sırasıyla "çalışma koşulları ve topluma katkı sağlamanın" etkili olduğunu; benzer şekilde, erkek öğretmen adaylarının da meslek seçiminde "kişisel özellikler, çalışma koşulları, topluma katkı sağlamak" dışında hayalini gerçekleştirme gibi nedenlerinin bulunduğunu tespit etmişlerdir.

Öğretmenlik mesleğini seçme nedenlerine bakıldığında öğretmen adaylarının "kişilik özelliklerine uygun olduğunu düşünmesi, topluma yararlı olmak istemesi, ailesinin öğretmen olması istemesi” sebebiyle öğretmenlik mesleğini seçmeyi uygun bulduğu anlaşılmıştır. Bu sonuçlara bakılarak öğretmen adaylarının, kişiliğine uygun olduğunu düşünerek, üniversite sınavlarında alınan puanlara bakarak, topluma faydalı olabileceğini göz önünde bulundurarak ve ailesinin yönlendirmelerini dikkate alarak öğretmenlik mesleğini seçme kararı aldıkları söylenebilir.

Öğretmenlerin öğretmenlik mesleğini yerine getirirken etkili olabilmeleri için, mesleğe yönelik tutumlarının olumlu olması beklenir. Bu araştırmada öğretmen adaylarının daha çok öğretmenliği "kişilik özelliklerine uygun olduğunu düşünerek, topluma yararlı olmak istedikleri için" seçtiklerini belirtmeleri öğretmenlik mesleğine yönelik tutumlarının olumlu olduğu şeklinde yorumlanabilir. Çakır (2005), Bulut ve Doğar (2006) da genel olarak öğretmen adaylarının öğretmenlik mesleğine yönelik tutumlarının olumlu olduğunu; Karacaoğlu (2008) öğretmenlik mesleği açısından yeterlik algılarının yüksek düzeyde olduğunu ortaya koymuştur.

$\mathrm{Bu}$ çalışmada da kız öğretmen adaylarının öncelikle kişilik özelliklerine uygun olması sebebiyle, öğretmenlik mesleğini tercih ettiği (\% 52), toplumsal fayda (\%50) ve aile isteğini (\%50) ikinci planda tuttukları ve son olarak sınav puanı yeterli olduğu için $(\% 42)$ öğretmen okuluna kayıt olmayı tercih ettikleri anlaşılmıştır. Erkek öğretmen adaylarının da, toplumsal fayda (\%50) ve aile isteğini (\%50) eşit oranda değerlendirdiği, ancak daha çok sınav puanının yetmesinin (\%58) sebebiyle eğitim fakültesine kayıt yaptırdığı anlaşılmıştır. Kızlarla kıyaslandığında erkek öğretmen (\%48) adaylarının kişiliğine uygun olmasını öncelikli değerlendirmediği anlaşılmıştır.

Bursal ve Buldur (2016) da kızların erkek adaylara göre geleceğe yönelik mesleki beklentilerinin daha olumlu olduğunu belirlemiştir. Pektaş ve Kamer (2011) kızların 
erkeklere göre öğretmenlik mesleğine daha olumlu baktığını; Çapri ve Çelikkaleli (2008), Oral (2004) ve Şeker, Deniz ve Görgen (2005) cinsiyetin adayların yeterlik inançları üzerinde önemli etkisinin olduğunu, benzer şekilde kızlar lehine farklılaştığını tespit etmişlerdir. Beşoluk ve Horzum (2011) ve Çermik, Doğan ve Şahin (2010) erkeklerle kıyaslandığında, kızların öğretmenlik meslek seçiminde kişisel nedenlerin etkili olduğunu belirlemişlerdir. Özsoy, Özsoy, Özkara ve Memiş (2010) yaptıkları araştırmalarında öğretmen adaylarının büyük bir çoğunluğunun öğretmenliği bilinçli olarak seçtiklerini; kızların seçim kararının idealizm, bilinç ve güvence boyutlarında erkeklerden yüksek olduğunu belirlemiştir.

$\mathrm{Bu}$ çalışmada, kız öğrencilerin kendilerini kişilik olarak uygun olarak hissetmesi, Türk toplumunun sosyal yapısıyla ilgili olabilir. Nitekim Türk toplumunda öğretmenlik mesleği, özellikle de sınıf öğretmenliği daha çok bir kadın mesleği olarak görülmekte ve sınıf öğretmenine anne gibi kutsal benzetmesi yapıldığından ve çocuk yetiştirme sorumluluğu genel olarak kadınlardan beklendiğinden, aileler kız çocuklarına sınıf öğretmenliğini daha fazla yakıştırabilmektedir.

Türkiye'de eğitim fakültesi öğrencileri MEB'in istihdam politikaları nedeniyle gelecek ve iş kaygısı yaşayabilmektedir. Bu konuda yapılan bir araştırma tıp fakültesi öğrencilerine kıyasla eğitim fakültesi öğrencilerinin istihdam edilme konusunda daha fazla kaygılı olduğunu göstermiştir (Özen, Ercan, Irgil ve Sığırl1, 2010). Ayrıca eğitim fakültesi öğrencileri atanabilmek için KPSS'yi kazanmak zorunda olduklarından, zorlanmakta hatta psikolojik sorunlar yaşayabilmektedir. Hatta KPSS'yi kazanma kaygısı adayların kaygı ve umutsuzluk düzeyini büyük ölçüde artmaktadır (Tümkaya, Aybek ve Çelik, 2007). Öğretmenlerin kendilerini mesleki anlamda yeterli olduğunu hissetmesi öğrenci başarısını, öğretimin kalitesini olumlu yönde etkileyebilmektedir (Guo, Connor, Yang, Roehrig ve Morrison, 2012). Bu nedenle bireysel olarak öğretmenlerin öğretme davranışına göre kendilerini nasıl bulduklarına yönelik inançlarının incelenmesi gerekir (Cho ve Shim, 2013). Bu noktada öğretmen adayı olma ümidiyle eğitim fakültesine başlayan lisans öğrencilerinin de mesleki anlamda kendilerini nasıl buldukları, onları kaygılandıran ve umutsuz olmalarına neden olan durumların incelenmesi yanında öğretmenlik mesleğine yönelik bakış açıları ve beklentilerinin değerlendirilmesi yararlı olabilir.

$\mathrm{Bu}$ çalışmada öğretmenlik mesleğini tercih edebilmeleri için öğretmen adaylarının, en fazla "öğretmenlik mesleğini layıkıyla yerine getirebilecek öğretmenler yetiştirilmeli” şeklinde beklenti içinde oldukları ve hizmet öncesi eğitimin önemine vurgu yaptıkları 
anlaşılmaktadır. Bazı öğretmen adaylarının da "öğretmen atamalarında KPSS'ye son verilmeli; eğitim fakülteleri kontenjanları ile atamalar orantılı bir şekilde düzenlenmeli; öğretmen yetiştiren kurumlar teorik değil uygulamaya dayalı eğitim vermeli, öğretmen seçiminde kişisel özelliklere bakılmalı; öğretmen yetiştiren kurumları değerler eğitimine önem vermeli" şeklinde beklenti içinde oldukları, az sayıda öğretmen adayının da "KPSS tek oturum halinde yapılmalı, meslek seçiminde gençlerin tercihlerine ve fikirlerine sayg1 duyulmalı" şeklinde öneriler geliştirdikleri tespit edilmiştir.

Göreve başladıktan sonra da (hizmet içi) gerçekleşmesini istediklerin şeylerin başında en fazla öğretmenlik mesleğinin saygınlığının, ikinci olarak öğretmenlerin gelir seviyesinin yükseltilmesini ve üçüncü olarak öğretmenlerin çalışma koşullarının iyileştirilmesini istedikleri anlaşılmıştır. Ancak oransal büyüklüklerine bakıldığında sonuçlar; kız öğretmen adaylarının hizmet öncesinde (\% 52) ve göreve başladıktan sonra (\%57) erkek öğretmen adaylarına (hizmet öncesi: \% 48 ve hizmet içi: \% 43) kıyasla daha fazla beklentiler içinde olduğu görülmüsşür. Cinsiyetler kendi içinde değerlendirildiğinde erkek öğretmen adaylarının (\%48) göreve başlamadan önce; kız öğretmen adaylarının da göreve başladıktan sonra (\%57) taleplerinin daha yüksek olduğu anlaşılmıştır.

İnsanların dışında olan ve onların çabası ile kolay kolay değiştiremeyecekleri değişkenler (yaş, cinsiyet, gelir, meslek, çalışma şartları, sahip olunan aile, statü gibi), insanların her yönden mutlu olmalarını açıklayan değişkenler olmasa da bireysel olarak iyi olmalarını açıklayan değişkenler arasında sayılmaktadır (Brief, Butcher, George ve Link, 1993).

$\mathrm{Bu}$ çalışmada olanaklar mümkün olsa hayattan beklentileriniz sorularına verilen cevaplar "bireysel hedefler" bağlamında; her türlü olanağınız bulunsa hangi mesleğe seçmek isterdiniz? Öğretmenlik mesleğinde mutlu olabilmeniz için nelerin değişmesini isterdiniz? sorularına verilen cevaplar da "mesleki hedefler" alt boyutunda değerlendirilmiştir.

Olanaklar mümkün olsa sorusuna verilen cevaplarda öğretmen adaylarının "bireysel olarak en çok isteği şeyin bireysel ihtiyaçlarını karşılamak", sonra sırasıyla "ailesini mutlu etmek başka insanlara yardımcı olmak, adil bir dünyada yaşamak, farklı konularda öğrenim görmek/kendini geliştirmek, fiziksel özelliklerini değiştirmek” gibi arzularının/isteklerinin olduğu anlaşılmıştır. Bazı kız öğretmen adaylarının, "yaşadığı yeri (ülkeyi/şehri) değiştirmek, kişilik özelliklerini değiştirmek ve dünyayı dolaşmak gibi erkeklerden farklı arzularının olduğu belirlenmiştir. Olanaklar mümkün olsa (düş/hayal), mesleki açıdan 
gerçekleşmesini istedikleri hayallerine bakıldığında, "sevebileceği işi yapmak, kendi işini kurmak, ekonomik anlamda getirisi yüksek bir iş sahibi olmak, statüsü yüksek bir iş sahibi olmak" gibi beklentiler içine girdikleri anlaşılmaktadır. Bu bulgular bazı öğretmen adaylarının hayallerinde olmak istediği mesleği seçemeyip, mevcut şartlara göre karar vermek durumunda kaldıklarını göstermektedir.

Öğretmen adaylarıyla yaptıkları araştırmalarında da Aksu, Engin-Demir, Daloğlu vd., (2010), Anılan ve Anılan (2014), Bursal ve Buldur (2013), Çermik, Doğan ve Şahin (2010) öğretmenlik programına kayıtlı öğretmen adaylarının bir kısmı için öğretmenlik mesleğinin ideal meslek olmadığını tespit etmişlerdir. Yeşilyurt ve Karakuş (2011) ise araştırmalarında, öğretmen adaylarının büyük çoğunluğunun seçtikleri branşın kişiliklerine uygun olduğu görüşünde birleştiklerini ancak, imkan verilmesi halinde ekonomi, tıp, mühendislik, branş olarak ise matematik, Türkçe ve coğrafyayı okumak istediklerini ortaya koymuştur.

“Öğretmenlik mesleğinde mutlu olabilmeniz için nelerin değişmesini isterdiniz?” sorusuna verdikleri cevaplarda öğretmen adaylarının, "KPSS sınavının kalkması, herkesin eşit/adil eğitim almasının sağlanması, öğretmenlerin mesleki standartlarının yükseltilmesi, öğretmenlerin gelirlerinin artırılması, okulların durumunun iyileştirilmesi, öğretmen atamalarının yapılması ve yetersiz olan öğretmenlerin işine son verilmesi/emekli edilmesi” gibi istekleri olduğu anlaşılmaktadır. Bunun dışında bazı kız öğretmen adaylarının "öğretmenlik mesleğine daha fazla değer verilmesi, eğitim yerlerinin sevgi yerlerine dönüşmesi ve herkesin kendi memleketine atanması" yönünde istekleri olduğu; sadece bir erkek öğretmen adayının da "öğretmenlik mesleğini herkesin severek yapması" yönünde arzusu olduğu anlaşılmıştır.

Kız ve erkek öğretmen adaylarının bireysel ve mesleki açıdan genel istekleri yüzde olarak incelendiğinde; olanaklar sunulmuş olsa kız öğretmen adaylarının bireysel arzularının $(\% 59)$ ve mesleki arzularının (\%52) erkek öğrencilere (bireysel \%41, mesleki, \%42) oranla daha fazla olduğu ve hayattan beklentilerinin daha yüksek olduğu tespit edilmiştir. Cinsiyetler kendi içinde değerlendirildiğinde, kızların bireysel anlamda, erkek öğretmen adaylarının mesleki anlamda, arzu ettikleri şeylerin oransal olarak daha yüksek olduğu anlaşılmıştır. 


\section{Öneriler}

Araştırma sonucunda, öğretmen adaylarının çoğunluğunun öğretmenlik mesleğinin daha çok dezavantajlı yönlerine vurgu yaptıkları, sınavla öğretmen atamalarının yapılmasını, öğretmenlik mesleğinin statüsünün düşük olmasını, öğretmenlerin çalışma şartlarının adil olmamasını ve lisans düzeyinde verilen eğitimin teorik olmasını eleştirdikleri anlaşılmıştır. Bu bulgulara dayanarak, öğretmenlik mesleğinin statüsünü yükseltecek önlemler alınması, öğretmenlerin çalışma koşullarının iyileştirilmesi, seçme/yerleştirme sınavlarının gözden geçirilmesi, lisans düzeyinde verilecek eğitimin teorik ve uygulamalı olacak şekilde yapılması önerilebilir. Türkiye'de öğretmenlerin işvereni konumunda olduğundan öğretmenlerin yetişme ve çalışma ölçütlerini MEB belirlemektedir. Bakanlık Eğitim fakültesi dışında, formasyon eğitimi almış olan lisans mezunlarını "kadrolu, sözleşmeli, ücretli öğretmenlik" gibi farklı uygulamalara başvurarak öğretmen olarak atayabilmektedir. Ancak statü bakımından ikilik yaratan farklı istihdam uygulamaları gençleri olumsuz etkilemektedir. Ayrıca meslek dışı kişilerin formasyon alarak öğretmen olarak atanmaları, eğitim fakülteleri kontenjanları ile atamaların orantılı bir şekilde düzenlenmeyişi, eğitim fakültesinde öğrenimlerine devam eden öğretmen adaylarının endişelenmelerine, dolayısıyla gelecek kaygısı yaşamalarına sebep olabilmektedir. Bu çalışmada öğretmen adaylarının mevcut sorunlar nedeniyle atanmaya yönelik kaygılarının olduğu tespit edilmiştir. $\mathrm{Bu}$ bulguya dayanarak öğretmen adaylarının geleceğe güvenle bakabilmeleri için Türkiye'de öğretmen istihdamında arz-talep dengesinin sağlanmasına yönelik çözümler üretilmesi önerilebilir.

Araştırmacılar "nitel, nicel ve karma araştırma desenleri” kullanarak yapacakları araştırmalarda gerek öğretmen yetiştiren fakülteler düzeyinde farklı branş öğretmen adaylarının (sınıf öğretmenliği, okul öncesi öğretmenliği, Türkçe öğretmenliği, sosyal bilgiler öğretmenliği, fen bilgisi öğretmenliği vs.) ve gerekse mesleğe yeni başlamış aday öğretmenlerin öğretmenlik mesleğine yönelik tutumları ve beklentilerini ortaya koyabilir. Gençlerin öğretmenlik mesleğine yönelik tutum ve beklentilerinin anlaşılması öğretmen yetiştirme ve öğretmen atamalarına yönelik politikaların geliştirilmesinde yol gösterici olabilir. $\mathrm{Bu}$ araştırma bulguları da öğretmenlik mesleğinin cazip bir meslek haline getirilmesi yönünde neler yapılması gerektiği yönünde fikir verebilir. 


\section{Kaynakça}

Aksoy, N. (2008). Birleştirilmiş sınıflarda eğitim-öğretim: genç ve deneyimsiz öğretmenlerin görüşlerine dayalı bir araştırma, Eğitim Bilim ve Toplum Dergisi, 6(21), 82-108.

Aksu, M., Engin-Demir, C., Daloglu, A., Yıldırım, S. ve Kiraz, E. (2010). Who are future teachers in Turkey? Characteristics of entering student teachers. International Journal of Educational Development, 30 (1), 91-101.

https://doi.org/10.1016/j.ijedudev.2009.06.005

Anılan, B. ve Anılan, H. (2014). Fen bilgisi öğretmen adaylarının fen bilgisi öğretmenliğini seçme nedenleri ve gelecek beklentileri. Ĕgitim ve Öğretim Araştırmaları Dergisi, 3(3), 51-64.

Beare, P., Marshall, J., Torgerson, C., Tracz, S., \& Chiero, R. (2012). Toward a culture of evidence: Factors affecting survey assessment of teacher preparation. Teacher Education Quarterly, 39, 159-173. https://files.eric.ed.gov/fulltext/EJ977361.pdf

Beşoluk, Ş. ve Horzum, M. B. (2011). Öğretmen adaylarının meslek bilgisi, alan bilgisi dersleri ve öğretmen olma isteğine ilişkin görüşleri. Ankara Üniversitesi Ĕ̆itim Bilimleri Fakültesi Dergisi, 44(1), 17-49.

Brief, A. P., Butcher, A. H., George, J. M., \& Link, K. E. (1993). Integrating bottom-up and top-down theories of subjective well-being: The case of health. Journal of Personality and Social Psychology, 64, 646-653. https://doi.org/10.1037/0022$\underline{3514.64 .4 .646}$

Brown, A. L., Lee, J., \& Collins, D. (2015). Does student teaching matter? Investigating preservice teachers' sense of efficacy and preparedness. Teaching Education, 26(1), 7793. https://doi.org/10.1080/10476210.2014.957666

Bulut, H. ve Doğar, Ç.(2006). Öğretmen adaylarının öğretmenlik mesleğine karş1 tutumlarının incelenmesi. Erzincan Eğitim Fakültesi Dergisi, 8(1), 13-27.

Bursal, M. ve Buldur, S. (2013). Fen bilgisi öğretmen adaylarının profillerinin değişimi: 2008-2012 y1lları arasında Cumhuriyet üniversitesi örneği. Cumhuriyet International Journal of Education, 2(4), 14-26.

Bursal, M. ve Buldur, S. (2016). İlköğretim öğretmen adaylarının meslek tercih nedenleri ve geleceklerine yönelik beklentileri: Karşılaştırmalı bir analiz. Abant İzet Baysal Üniversitesi Ĕgitim Fakültesi Dergisi, 16(2), 351-376. 
Boz, Y., ve Boz, N.( 2008). Kimya ve matematik öğretmen adaylarının öğretmen olma nedenleri. Kastamonu Ĕ̈itim Dergisi, 16(1), 137-144.

Cho, Y. \& Shim, S. S. (2013). Predicting teachers' achievement goals for teaching: The role of perceived school goal structure and teachers' sense of efficacy. Teaching and Teacher Education, 32, 12-21. https://doi.org/10.1016/j.tate.2012.12.003

Connelly, L. M. (2016). Trustworthiness in qualitative research. Medsurg Nursing, 25(6), 435-437.

Creswell, J. (2014). Nitel araştırma yöntemleri. (Gözden Geçirilmiş 2. Bask1). Ankara: Siyasal Kitabevi.

Çakır, Ö. (2005). Anadolu üniversitesi açıköğretim fakültesi İngilizce öğretmenliği lisans programı ve eğitim fakülteleri İngilizce öğretmenliği lisans programı öğrencilerinin mesleğe yönelik tutumları ve mesleki yeterlik algıları. İn̈nü Üniversitesi Ĕ̆itim Fakültesi Dergisi, 6 (9), 27-42.

Çapri, B. ve Çelikkaleli, Ö. (2008). Öğretmen adaylarının öğretmenliğe ilişkin tutum ve mesleki yeterlik inançlarının cinsiyet, program ve fakültelerine göre incelenmesi. İnönü Üniversitesi Ĕgitim Fakültesi Dergisi, 9(15), 33-53.

Çermik, H., Doğan, B. ve Şahin, A. (2010). Sınıf öğretmenliği öğretmen adaylarının öğretmenlik mesleğini tercih sebepleri. Pamukkale Üniversitesi Eğitim Fakültesi Dergisi, 28, 201-212. https://dergipark.org.tr/tr/pub/pauefd/issue/11115/132919

Çınkır, Ş. ve Kurum, G. (2017). Atanmak ya da atanamamak: Ücretli öğretmenlerin yaşadıkları sorunlar. Eğitimde Nitel Araştırmalar Dergisi, 5(3), 9-35. $\underline{10.14689 / i s s n .2148-2624.1 .5 \mathrm{c} 3 \mathrm{~s} 1 \mathrm{~m}}$

Denzin, N. K., \& Giardina, M. D. (2011). Qualitative inquiry and global crises. CA: Left Coast Press.

Deringöl, Y. (2007). Türkiye'de cumhuriyet döneminden günümüze ilköğretim öğretmenleri yetiştirilmesinin tarihsel boyutu ve eğitimcilerin görüşlerinin değerlendirilmesi üzerine bir araştırma. Hasan Ali Yücel Eğitim Fakültesi Dergisi, 2, 17-27.

Duran, E., Sezgin, F.ve Çoban, O. (2011). Aday sınıf öğretmenlerinin uyum ve sosyalleşme sürecinin incelenmesi. Dumlupınar Üniversitesi, Sosyal Bilimler Dergisi, 31, 465478. https://dergipark.org.tr/tr/pub/dpusbe/issue/4773/65722

Gömleksiz, N., Kan, A. Ü., Biçer, S., ve Yetkiner, A. (2010). Mesleğe yeni başlayan sınıf öğretmenlerinin yaşadıkları zorluklarla öğretmen adaylarının yaşayabilecekleri zorluklara ilişkin algılarının karşılaştırılması. E-Journal of New World Sciences Academy, 5(3), 12-23. 
Guo, Y., Connor, C. M., Yang, Y., Roehrig, A. D. \& Morrison, F. J. (2012). The effects of teacher qualification, teacher self-efficacy, and classroom practices on fifth graders' literacy outcomes. The Elementary School Journal, 113, 3-24. https://www.journals.uchicago.edu/doi/abs/10.1086/665816

Hacıömeroğlu, G. ve Taşkın, Ç. Ş. (2010). Fen bilgisi öğretmenliği ve ortaöğretim fen ve matematik alanları (OFMA) eğitimi bölümü Öğretmen adaylarının öğretmenlik mesleğine ilişkin tutumları, Ahi Evran Üniversitesi Ĕ̆itim Fakültesi Dergisi, 11(1),77-90.

Ingersoll, R. \& Strong, M. (2011). The impact of induction and mentoring programs for beginning teachers: A critical review of the research. Review of Education Research, 81(2), 201-233. https://doi.org/10.3102/0034654311403323

Johnson, B. \& Christensen, L. (2008). Educational Research: quantitative, qualitative, and mixed approaches. New York: Sage.

Kakuru, D. M. ve Paradza, G. G. (2007). Reflections on the use of the life history method in researching rural African women: field experiences from Uganda and Zimbabwe. Gender \& Development, 15 (2), 287-297.

https://doi.org/10.1080/13552070701391581

Karacaoğlu, Ö. C. (2008). Öğretmenlerin yeterlilik algıları. Yüzüncü Yıl Üniversitesi, Eğitim Fakültesi Dergisi. 5(1), 70-97.

Karataş, Z. ve Yavuzer, Y. (2015). Bireyi tanımada test dışı teknikler. Ankara: Nobel Yayınları.

Karge, B. D. (1993). Beginning teachers: In danger of attrition. American Educational Research Association. Atlanta: GA.

Kıroğlu, K. (2008). Eğitim bilimine giriş, Ö. Demirel ve Z. Kaya (Ed.). Bir meslek olarak ögretmenlik (344-372). Ankara: Pegem Akademi.

Korkmaz, İ., Saban, S. A., ve Akbaşl1, S. (2004). Göreve yeni başlayan sınıf öğretmenlerinin karşılaştıkları güçlükler. Kuram ve Uygulamada Eğitim Yönetimi, 38(55), 266-277.

Kozikoğlu, İ. (2016). Öğretimin ilk yılı: mesleğin ilk yılındaki öğretmenlerin karşılaştıkları güçlükler, hizmet öncesi ĕgitim yeterlikleri ve mesleğe adanmışlıkları. Yayımlanmamış doktora tezi, Yüzüncü Yıl Üniversitesi Eğitim Bilimleri Enstitüsü, Van.

Lincoln, Y.S. \& Guba, E.G. (1985). Naturalistic inquiry. California: Sage Publsing.

Merriam, B. S. (2014). Nitel araştırma. S. Turan vd, (Çev). Ankara: Nobel Yayıncılık. 
Merriam, S. B., and Grenier, R. S. (2019). Qualitative research in practice: Examples for discussion and analysis. San Francisco, CA: Jossey-Bass Publishers

MEB. (2013). Mesleki gelişim etkinlik programı. http://www.mebpersonel. com/yerdegistirme/yeni-atanan-ogretmenlerin-uyum-egitimiprogrami-h89491.html. 2013.

MEB (2015). Milli ĕgitim bakanliğl öğretmen atama ve yer değiştirme yönetmeliği. 17 Nisan 2015 tarih ve 29329 sayıl1 Resmi Gazete.

MEB (2016a). 02.03.2016 tarihli ve 2456947 sayılı makam oluru ile yürürlüğe giren aday öğretmen yetiştirme sürecine ilişkin yönerge.

MEB (2016b). Aday ögretmen yetiştirme programı. http://oygm.meb.gov.tr/www/adayogretmen-yetistirmesurecine-iliskinyonerge-ve-yetistirme-programi/icerik/328

Miles, M, B., \& Huberman, A. M. (1994). Qualitative data analysis: An expanded Sourcebook. (2th ed). Thousand Oaks, CA: Sage.

Nayir, K. F., ve Taneri, P. O. (2013). Karatekin Üniversitesi pedagojik formasyon öğrencilerinin öğretmenlik mesleğini seçme nedenlerine ilişkin görüşlerinin cinsiyet değişkenine göre incelenmesi. Çankırı Karatekin Üniversitesi Karatekin Edebiyat Fakültesi Dergisi, 2(2), 1-13.

Neuman, L. W. (2014). Social research methods: Qualitative and quantitative approaches (7th ed.). Essex: Pearson Education Limited

Okutan, M. ve Aydoğdu, F. G. O. (2009). Adaylık eğitiminin aday öğretmenlerin görüşlerine göre değerlendirilmesi, Milli Eğitim Dergisi. 38(183), 190-201.

Oral, B. (2004). Eğitim fakültesi öğrencilerinin öğretmenlik mesleğine ilişkin tutumları. Eğitim Araştırmaları Dergisi, 15, 88-98.

Özbek, R., Kahyaoğlu, M. ve Özgen, N. (2007). Öğretmen adaylarının öğretmenlik mesleğine yönelik görüşlerinin değerlendirilmesi. Afyon Kocatepe Üniversitesi Sosyal Bilimler Dergisi. 9(2), 221-232.

Özen, N. S., Ercan, I., Irgil, E. ve Sığırlı, D. (2010). Anxiety prevalence and affecting factors among university students. Asia-Pacific Journal of Public Health,22(1),127133. https://doi.org/10.1177/1010539509352803

Özsoy, G., Özsoy, S., Özkara, Y. ve Memiş, A. D. (2010). Öğretmen adaylarının öğretmenlik mesleğini tercih etmelerinde etkili olan faktörler. Illkögrretim Online, 9(3), 910-921. https://hdl.handle.net/20.500.12628/1342

Patton, M. Q. (2014). Nitel araştırma ve değerlendirme yöntemleri. Bütün, M. ve Demir, B. (Çev.) İstanbul: Pegem Akademi. 
Pektaş, M. ve Kamer, S. T. (2011). Fen bilgisi öğretmen adaylarının öğretmenlik mesleğine yönelik tutumları, Türk Ĕ̈itim Bilimleri Dergisi, 9(4), 829-850.

Poch, F. V., Villar, E., Caparros, B., Juan, J., Cornella, M., \& Perez, I. (2004). Feelings of hopelessness in a Spanish university population: Descriptive analysis and its relationship to adapting to university, depressive symptomatology and suicidal ideation. Social Psychiatry and Psychiatric Epidemiology, 39(4), 326-334. https://doi.org/10.1007/s00127-004-0756-2

Punch, K. (2014). Sosyal araştırmalara giriş: Nicel ve nitel yaklaşımlar. D. Bayrak, H.B. Arslan, Z Akyüz (Çev.) Ankara: Siyasal Kitabevi.

Quaglia R. (1989). Socialization of the beginning teacher: A theoretical model from the empirical literature. Research in Rural Education, 5(3), 1-7.

Sarı, M. H., ve Altun, Y. (2015). Göreve yeni başlayan sınıf öğretmenlerinin karşılaştıkları sorunlar. Hacettepe Üniversitesi Ĕ̌itim Fakültesi Dergisi, 30(1), 213-226.

Şeker, H., Deniz, S., ve Görgen, İ. (2005). Tezsiz yüksek lisans öğretmen adaylarının öğretmenlik yeterlikleri üzerine değerlendirmeleri. Kuram ve Uygulamada Eğitim Yönetimi Dergisi, 42, 237-253.

Soydan, T. (2012). Eğitimin yapısal dönüşümü bağlamında öğretmenlerin istihdamı: istihdam biçimi farklılıkları üzerine öğretmen ve yönetici görüşlerine dayalı bir araştırma. Trakya Üniversitesi Eğitim Fakültesi Dergisi, 2(2), 1-13.

Taşkaya, S. M., Turhan, M., ve Yetkin, R. (2015). Kırsal kesimde görev yapan sınıf öğretmenlerinin sorunları (Ağrı İli Örneği), Uluslararası Avrasya Sosyal Bilimler Dergisi, 6(18), 198-210.

Tataroğlu, B., Özgen, K., ve Alkan, H. (2011). Matematik öğretmen adaylarının öğretmenliği tercih nedenleri ve beklentileri. In 2nd International Conference on New Trends in Education and Their Implications (27-29). Antalya, Turkey.

Toker-Gökçe, A. (2013). Eğitim fakültesi mezunu sınıf öğretmenlerinin adaylık dönemlerinde yaşadıkları mesleki sorunlar. Dicle Üniversitesi Ziya Gökalp Eğitim Fakültesi Dergisi, 21, 137-156.

Tunçbilek, M. M. ve Tünay, T. (2017). MEB aday öğretmen yetiştirme süreci uygulamasının ilgili tarafların bakış açısıyla değerlendirilmesi. Elektronik Sosyal Bilimler Dergisi, 16(61), 412-427. https://doi.org/10.17755/esosder.304683

Tümkaya, S., Çelik,M., ve Aybek, B. (2011). Lise öğrencilerinde boyun eğici davranışlar, otomatik düşünceler, umutsuzluk ve yaşam doyumunun incelenmesi. Çukurova Üniversitesi Sosyal Bilimler Enstitüsü Dergisi, 20(2), 77-94. 
Ubuz, B. ve Sarı, S. (2008). Sınıf öğretmeni adaylarının öğretmenlik mesleğini seçme nedenleri. Pamukkale Üniversitesi Ĕ̆itim Fakültesi Dergisi, 24(2), 113-119.

Williams, J., \& Forgasz, H. (2009). The motivations of career change students in teacher education. Asia Pacific Journal of Teacher Education, 37(1), 95-108. https://doi.org/10.1080/13598660802607673

Yang, L. (2008). The life stories of motherhood among divorced women in Taiwan. Journal of Nursing Research, 6(3), 220-229.

Yeşilyurt, E., ve Karakuş, M. (2011). Öğretmenlerin adaylık sürecinde karşılaştıkları problemler. International Online Journal of Educational Sciences, 3(1), 261-293.

Yıldırım, A. ve Şimşek, H. (2018). Sosyal bilimlerde nitel araştırma yöntemleri (Genişletilmiş 11. Baskı). Ankara: Seçkin Yayıncılık. 